\title{
Inflammatory Mechanisms Contributing to Endothelial Dysfunction
}

\author{
Panagiotis Theofilis ${ }^{1}\left(\mathbb{D}\right.$, Marios Sagris ${ }^{1}$, Evangelos Oikonomou ${ }^{1,2}{ }^{\circledR}$, Alexios S. Antonopoulos ${ }^{1}$, \\ Gerasimos Siasos ${ }^{1,2}$, Costas Tsioufis ${ }^{1}$ and Dimitris Tousoulis ${ }^{1, *}$ \\ 1 1st Department of Cardiology, Hippokration General Hospital, University of Athens Medical School, \\ 11527 Athens, Greece; panos.theofilis@hotmail.com (P.T.); masagris1919@gmail.com (M.S.); \\ boikono@gmail.com (E.O.); alexios.antonopoulos@cardiov.ox.ac.uk (A.S.A.); ger_sias@hotmail.com (G.S.); \\ ktsioufis@gmail.com (C.T.) \\ 2 3rd Department of Cardiology, Thoracic Diseases General Hospital Sotiria, University of Athens Medical \\ School, 11527 Athens, Greece \\ * Correspondence: drtousoulis@hotmail.com
}

check for updates

Citation: Theofilis, P.; Sagris, M.; Oikonomou, E.; Antonopoulos, A.S.; Siasos, G.; Tsioufis, C.; Tousoulis, D. Inflammatory Mechanisms Contributing to Endothelial Dysfunction. Biomedicines 2021, 9, 781 . https://doi.org/10.3390/ biomedicines 9070781

Academic Editor: Pasquale Ambrosino

Received: 15 June 2021

Accepted: 4 July 2021

Published: 6 July 2021

Publisher's Note: MDPI stays neutral with regard to jurisdictional claims in published maps and institutional affiliations.

Copyright: (c) 2021 by the authors. Licensee MDPI, Basel, Switzerland. This article is an open access article distributed under the terms and conditions of the Creative Commons Attribution (CC BY) license (https:// creativecommons.org/licenses/by/ $4.0 /)$.

\begin{abstract}
Maintenance of endothelial cell integrity is an important component of human health and disease since the endothelium can perform various functions including regulation of vascular tone, control of hemostasis and thrombosis, cellular adhesion, smooth muscle cell proliferation, and vascular inflammation. Endothelial dysfunction is encompassed by complex pathophysiology that is based on endothelial nitric oxide synthase uncoupling and endothelial activation following stimulation from various inflammatory mediators (molecular patterns, oxidized lipoproteins, cytokines). The downstream signaling via nuclear factor- $\mathrm{kB}$ leads to overexpression of adhesion molecules, selectins, and chemokines that facilitate leukocyte adhesion, rolling, and transmigration to the subendothelial space. Moreover, oscillatory shear stress leads to pro-inflammatory endothelial activation with increased monocyte adhesion and endothelial cell apoptosis, an effect that is dependent on multiple pathways and flow-sensitive microRNA regulation. Moreover, the role of neutrophil extracellular traps and NLRP3 inflammasome as inflammatory mechanisms contributing to endothelial dysfunction has recently been unveiled and is under further investigation. Consequently, and following their activation, injured endothelial cells release inflammatory mediators and enter a pro-thrombotic state through activation of coagulation pathways, downregulation of thrombomodulin, and an increase in platelet adhesion and aggregation owing to the action of von-Willebrand factor, ultimately promoting atherosclerosis progression.
\end{abstract}

Keywords: endothelial dysfunction; inflammation; Nf-кB; adhesion molecules; selectins; NLRP3 inflammasome; shear stress

\section{Introduction}

Cardiovascular diseases represent the primary cause of morbidity and mortality in western societies despite the breakthroughs in their diagnosis, treatment, and prevention. Several risk factors are implicated in their pathogenesis, such as arterial hypertension, diabetes mellitus (DM), smoking, and obesity. Interestingly, most of these processes are linked with endothelial dysfunction, the initial step of atherogenesis, which has been proven to be a precursor of adverse cardiovascular outcomes [1-4]. Recently, a lot of interest has been shown on the pro-inflammatory state stemming from the cluster of comorbidities frequently encompassing patients with cardiovascular diseases and its deleterious effect on atherosclerosis. Therefore, in the context of this narrative review, we present the inflammatory mechanisms involved in the development of endothelial dysfunction and the potential therapeutic implications according to the latest preclinical and clinical studies. 


\section{Physiology of the Vascular Endothelium}

\subsection{Endothelial Cell Anatomy and Function}

The endothelium is an abundant organ consisting of a squamous cell monolayer that lines blood vessels, being in contact with the flowing blood. It consists of polarized endothelial cells (EC) adjacent to a basal lamina, together forming the tunica intima of blood vessels. ECs are frequently described as thin and slightly elongated with average dimensions of 30-50 $\mu \mathrm{m}$ length, $10-30 \mu \mathrm{m}$ width, and $0.1-1 \mu \mathrm{m}$ height. They are positioned along the vessel axis to mitigate the shear stress (SS) deriving from the blood flow. Even though once believed to be just a bystander, the endothelium has now been established as an endocrine organ, regulating the exchange of fluids, nutrients, and metabolites, and is characterized as a crucial mediator of various functions. Among their well-described properties is vascular tone regulation via vasoconstriction or relaxation, vascular remodeling, control of hemostasis and thrombosis, cellular adhesion, smooth muscle cell proliferation, and vascular inflammation as long as ECs remain in a healthy state $[5,6]$.

\subsubsection{Regulation of Vascular Tone}

The discovery of prostacyclin and its endothelial-related synthesis along with the work from Furchgott and Zawadzki concerning endothelial nitric oxide (eNO) demonstrated the importance of endothelium in vascular relaxation [7-9]. Consequently, tissue oxygen supply is dependent upon synthesis and release of $\mathrm{NO}$, endothelial-derived hyperpolarizing factor (EDHF), arachidonic acid metabolites signaling via cyclooxygenase, lipoxygenase, and cytochrome P450 while the role of various molecules (angiotensin II (ATII), endothelin, urotensin, C-type natriuretic peptide, bradykinin, adrenomedullin, adenosine, purines, reactive oxygen species (ROS)) is vital in achieving the balance in vascular tone [10].

\subsubsection{The Role of Nitric Oxide}

Nitric oxide is a molecule with pleiotropic functions in endothelial function. It is synthesized from L-arginine in endothelial cells, with calcium-calmodulin-dependent NO synthase (NOS) acting as a catalyst for this reaction. Three different subtypes of NOS (neuronal NOS (nNOS), inducible NOS (iNOS), and endothelial NOS (eNOS)) have been reported, each having different structural and functional characteristics. Calcium-dependent enzymes nNOS and eNOS are the constitutive NOS while iNOS is induced by immunological stimuli. Among the known required NOS co-factors are oxygen, nicotinamide adenine dinucleotide phosphate (NADPH), and tetrahydrobiopterin $\left(\mathrm{BH}_{4}\right)$ [11]. Following its synthesis, it is distributed from the endothelial cell membrane to vascular smooth muscle cells leading to the activation of guanylate cyclase, which then converts GTP to cGMP, ultimately resulting in the removal of calcium and consequent relaxation of cells [12].

Other than its role in mediating the vascular tone via relaxation of smooth muscle cells, NO has an antithrombotic role due to the attenuation of platelet activation and aggregation, regulates the migration and adhesion of leukocytes on EC, and inhibits vascular smooth muscle cell proliferation [11]. Moreover, it has been implicated in the maintenance of endothelial integrity and permeability [13]. It should also be noted that NO is a potent oxygen free radical scavenger by enhanced decomposition of peroxynitrite to nitrate and nitrite and inhibition of neutrophil-related $\mathrm{O}^{-}{ }_{2}$ production via limiting $\mathrm{NADPH}$ oxidase activity $[14,15]$.

\section{Assessment of Endothelial Function}

Several methods aiming at estimating endothelial function have been investigated and validated during the past decades. The main objective stemming from those examinations is the demonstration of vasodilation following a stimulus, either that being a vasodilating substance such as acetylcholine or reactive hyperemia-induced high shear stress, leading to an increase in $\mathrm{NO}$ and other endothelium-derived factors [16,17].

Invasive methods of endothelial function assessment are applied in the clinically relevant coronary circulation. In the setting of coronary angiography or intravascular 
ultrasound, the healthy endothelium leads to vessel dilation following administration of acetylcholine or other endothelial vasodilators whereas in endothelial dysfunction a lower vasodilatory response or even vasoconstriction might be observed. On the level of coronary microvasculature, alterations between baseline and coronary blood flow following stimulation with adenosine define coronary flow reserve (CFR) which is, however, affected by both endothelium and non-endothelium dependent mechanisms [6]. Even though these methods are considered the gold standard, their invasive nature and increased cost limit their widespread application and are only employed in patients requiring cardiac catheterization for other indications. Venous occlusion plethysmography is a semi-invasive approach via the unilateral cannulation of the brachial artery followed by administration of vasoactive agents and subsequent quantification of endothelium-dependent and independent vessel dilation, with the contralateral arm serving as a control [18].

The most frequently used method of endothelial function assessment has undoubtedly been flow-mediated dilation (FMD) of the brachial artery. After occlusion of the brachial artery via a blood pressure cuff inflated usually $50 \mathrm{mmHg}$ over the systolic blood pressure of the participant for 5 minutes, reactive hyperemia ensues leading to an increase in endothelial shear stress which is a known NO stimulus [19]. Even though it is easily accessible, cost-effective, and correlates adequately with invasive measurements, the existence of various protocols (cuff position, duration-magnitude of occlusion, time stamps for post-deflation measurements), as well as significant inter- and intra-observer variability, are important limitations $[19,20]$. Over time, changes in FMD may add prognostic information regarding future cardiovascular risk [21,22]. Moreover, FMD has been correlated with several biomarkers of atherosclerosis and heart failure $[23,24]$.

Finger plethysmography is another non-invasive method of estimating endothelial function [25]. It is based on the recording of finger arterial pulse amplitude by pneumatic probes after reactive hyperemia induction similarly to the FMD technique and the index between the examined and the control arm is calculated. However vascular dilatation is partially NO-dependent using this method [26], and it has been reportedly associated with coronary microvascular function but not with brachial artery FMD [27-29]. Lastly, retinal endothelial function assessment via provocation with flicker light has been recently proposed since vasoreaction is also partially dependent on NO. Although knowledge is still limited and no standardization protocols have been established [30], the retinal endothelial function has been linked with various diseases including diabetes mellitus [31], obesity [32], heart failure [33], and hypertension [34].

With regards to biomarkers of endothelial dysfunction, adhesion molecules, selectins, and prothrombotic molecules have been used in the past for the assessment of endothelial function, correlating well with traditional cardiovascular risk factors and incident cardiovascular risk despite having important drawbacks. Lately, interest has been shifted towards endothelial microparticles as a more specific means of endothelial function estimation, while studies have suggested a predictive value towards cardiovascular risk [35]. Endocan has also been described as an endothelial-specific marker that could be employed in disease states characterized by a dysfunctional endothelium [36].

\section{Pathophysiology of Endothelial Dysfunction}

\section{1. eNOS Uncoupling}

Endothelial dysfunction is the result of an imbalance between vasodilators and vasoconstrictors produced by endothelial cells, leading to an atheroprone phenotype consisting of vasoconstriction, leukocyte trafficking, inflammation, and coagulation-thrombosis. Reduced synthesis and availability of NO, due to impaired eNOS expression and activity, is frequently the initial mediator of endothelial dysfunction. In conditions of increased oxidative stress, the insufficient concentration of co-factors drives the production of superoxide instead of $\mathrm{NO}$, a process known as $\mathrm{NO}$ uncoupling, with harmful downstream effects such as the generation of the pro-oxidant peroxynitrite which promotes mitochondrial and endothelial cell dysfunction [37,38]. 
The low bioavailability of the required co-factor $\mathrm{BH}_{4}$ has been proven to be the major determinant of $\mathrm{NO}$ uncoupling due to ROS-induced oxidation to $\mathrm{BH}_{2}$ [39]. Moreover, the inability of a salvage pathway of $\mathrm{BH}_{4}$ production, by recycling of oxidized $\mathrm{BH}_{2}$ to $\mathrm{BH}_{4}$ through the action of dihydrofolate reductase (DHFR), has also been reported through depletion of DHFR enzyme [40,41]. The role of NADPH oxidase in the reduced $\mathrm{BH}_{4}$ bioavailability has been long established [41,42].

Asymmetric dimethylarginine (ADMA) is a known endogenous inhibitor of NO formation through competition with L-arginine at the active NOS site [43]. Its synthesis is based on the proteolysis of methylated arginine, after its modification by protein-arginine methyltransferases [44]. Studies have also reported associations of endothelial ADMA with oxidative stress and superoxide production, highlighting its role in endothelial dysfunction [45]. Moreover, ADMA-induced oxidative stress could be the result of depleted $\mathrm{BH}_{4}$ stores, further leading to eNOS uncoupling and enhanced superoxide production. Last but not least, a pro-inflammatory role of ADMA has also been described [46], owing to leukocyte adhesion and the production of inflammatory mediators [47].

\subsection{Cardiovascular Risk Factors and Endothelial Dysfunction \\ 4.2.1. Smoking}

Tobacco and electronic cigarette smoking have been repetitively proven to adversely affect endothelial function by promoting oxidative stress [48,49]. The role of cyclooxygenases (COX), particularly COX-1, in endothelial activation following cigarette smoking has been also demonstrated [50]. Additionally, cigarette smoke constituents have been related to $\mathrm{BH}_{4}$ depletion and eNOS uncoupling, which promote endothelial dysfunction [51]. However, these deleterious actions on vascular endothelium appear to be partially reversible after cessation of smoking [52-54].

\subsubsection{Diabetes Mellitus}

Diabetes mellitus, a global pandemic with increasing incidence and disastrous vascular complications [55], has been implicated in endothelial dysfunction. Hyperglycemia leads to disturbed NO bioavailability and ROS production, with overproduction of advanced glycation end products (AGEs), overexpression of their receptors (RAGE), and hexosamine pathway activation being also involved [56]. Indeed, initial preclinical studies have pointed to oxidative stress as the earliest abnormality in diabetes mellitus natural history [57].

\subsubsection{Arterial Hypertension}

Moving on to arterial hypertension, its deleterious effect on endothelial function has been consistently proven in animal as well as human studies [58], while a prognostic role of endothelial dysfunction in hypertensives has also been documented [59]. An increase in ROS has been the principal finding in studies evaluating possible pathophysiologic mechanisms that include increased expression of NADPH oxidase (NOX) [60], ADMA [61], endothelin-1 [62], and angiotensin-II [63].

\subsubsection{Hypercholesterolemia}

Concluding with hypercholesterolemia, the role of oxidized low-density lipoprotein (oxLDL) is crucial in the development of endothelial dysfunction. High amounts of oxLDL lead to an imbalance of eNOS and iNOS mediated by High-mobility group box 1 (HMGB1)toll-like receptor (TLR) pathway and lectin-type oxLDL receptor 1 (LOX-1)-nuclear factor$\kappa B(N F-\kappa B)$ pathway respectively, ultimately resulting in endothelial dysfunction due to EC apoptosis and reduced protective autophagy [64]. Even though oxLDL impairs endothelial function, this effect appears to be reversible via the action of high-density lipoprotein [65]. Lipoprotein(a) has recently emerged as a marker of increased cardiovascular risk, with preliminary experimental data reporting adverse endothelial effects via the activation of monocytes [66]. However, further investigation is required to elucidate its role in endothelial function. 


\section{The Role of Inflammation in Endothelial Dysfunction}

In cases of infections or tissue injury, endothelial cells undergo morphological and functional modifications. This process, termed endothelial activation, is triggered by various stimuli including bacterial endotoxins, inflammatory cytokines (tumor necrosis factor (TNF)- $\alpha$, ILs, and interferon- $\gamma$ ), or pattern recognition receptor activation (PRR) following the identification of pathogen-associated molecular patterns (PAMPs) or damage-associated molecular patterns (DAMPs) $[67,68]$. Examples of such PRR with implications in endothelial dysfunction include toll-like receptors (TLRs) and NOD-like receptors (NLRs), among others [69]. Following activation of PRRs, upregulation of pro-inflammatory molecule expression leads to an increasing burden of sustained inflammation with local and systemic complications (Figure 1) [70].

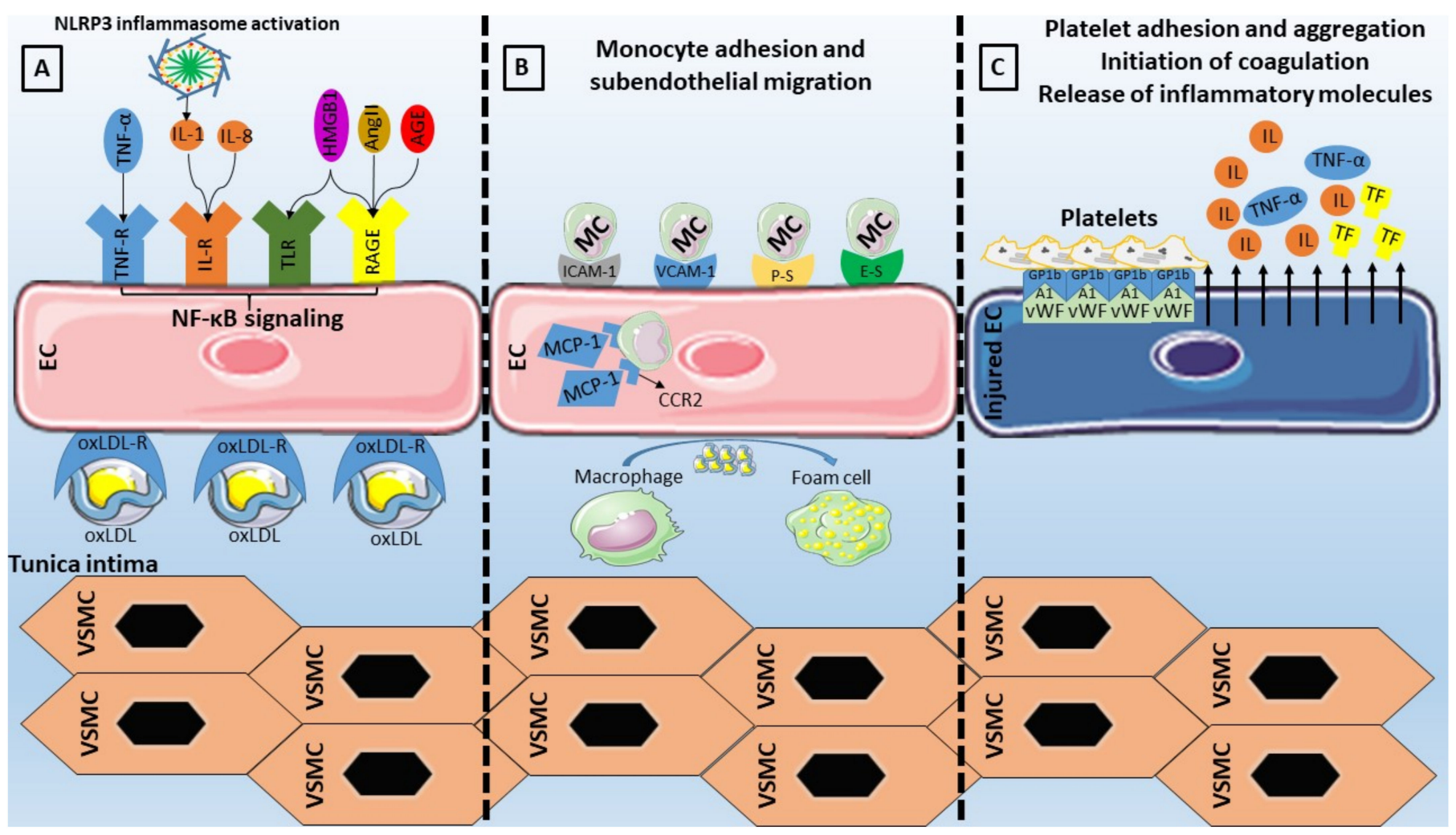

Figure 1. Inflammatory activation of endothelial cells (ECs). (A) Stimulation of EC receptors by damage-associated molecular patterns (High mobility group box 1 (HMGB1)), inflammatory cytokines (tumor necrosis factor (TNF)- $\alpha$, interleukins (ILs)), oxidized low-density lipoproteins (oxLDL), advanced glycation end products (AGEs), and angiotensin (Ang)-II promotes nuclear factor- $\mathrm{kB}(\mathrm{NF}-\mathrm{\kappa B})$ signaling which results in (B) upregulation of adhesion molecules (vascular cell adhesion molecule (VCAM)-1, intercellular adhesion molecule (ICAM)-1, E-Selectin (E-S), P-Selectin (P-S)) with subsequent monocyte (MC) adhesion and subendothelial transmigration with the aid of monocyte chemoattractant protein (MCP)-1 and its receptor C-C chemokine receptor type 2 (CCR2). Monocytes proceed to differentiate into macrophages that phagocytose oxLDL to become foam cells. (C) Injured endothelial cells release inflammatory mediators and tissue factor (TF) further promoting inflammation and coagulation, while the release of von-Willebrand factor (vWF) from the Weibel-Palade bodies results in platelet adhesion and aggregation following the binding with platelet glycoprotein (GP)1b. NLRP3: NLR family pyrin domain containing 3, TLR: toll-like receptor, RAGE: receptor of advanced glycation end products, VSMC: vascular smooth muscle cell.

\subsection{TLRs and Endothelial Dysfunction}

TLRs are important regulators of the immune system due to their pattern recognition and the ability to initiate inflammation. Two distinct pathways have been described upon activation of a TLR; the myeloid differentiation primary response protein 88 
(MyD88)-dependent pathway involving the early phase NF-kB activation and the myD88independent pathway associated with the late phase NF- $\kappa B$ activation [71].

HMGB1, a major non-histone protein that is overexpressed in the setting of DM [72], is one of the most well-studied DAMPs firmly correlating with chronic low-grade inflammation [73]. Its ability to bind with TLR4 and RAGE leads to activation of the immune system and the initiation of inflammation [74]. Moreover, increased trimethylamine Noxide (TMAO) in the setting of gut dysbiosis was recently found to be related to endothelial cell dysfunction through an HMGB1-TLR4 pathway [75]. Arterial hypertension is another TLR4 stimulus owing to the action of angiotensin II as demonstrated in aortic samples of hypertensive rats [76]. Eventually, and following TLR4 activation, downstream inhibition of antioxidant enzymes, activation of NADPH oxidase, and upregulation of pro-inflammatory cytokines production lead to endothelial cell dysfunction.

\subsection{NLRP3 Inflammasome and Endothelial Dysfunction}

Inflammasomes, first mentioned nearly two decades ago, have been described as crucial in the innate immunity processes, implicated in inflammatory diseases' natural history $[77,78]$. The most well-characterized member has undoubtedly been the NLRP3 inflammasome, with research showing associations with multiple diseases with deregulated inflammation and dysfunctional endothelium (DM, arterial hypertension, obesity, atherosclerosis) [79-82].

NLRP3 inflammasome activation can be the outcome of various signals, namely ion fluxes, mitochondrial dysfunction, and ROS overproduction [83], while noncanonical and alternative activation have also been proposed $[84,85]$. Interestingly the alternative NLRP3 inflammasome activation, involving the TLR4-TIR-domain-containing adaptor-inducing interferon- $\beta$ (TRIF)-receptor-interacting serine/threonine-protein kinase 1 (RIPK1)-Fasassociated protein with death domain (FADD)-CASP8 signaling pathway, is not involved in pro-inflammatory cell death (pyroptosis) [85].

In chronic low-grade inflammatory diseases, such as cardiovascular diseases, an increased burden of ROS has been observed. ROS-induced inflammation via expression of inflammatory cytokines, including IL- $1 \beta$, has been linked with NLRP3 inflammasome activation, which is essential for the proteolytic cleavage of those inflammatory mediators [86]. Available knowledge points towards autophagy and ROS as negative and positive regulators of NLRP3 inflammasome. Cardiovascular risk factors are also implicated, with obesity-induced inhibition of mitophagy and cholesterol crystal-induced inflammasome activation resulting in IL-1ßand IL-18 production [87-89].

\subsection{The Role of NF- $\kappa B$ and Adhesion Molecules}

Upon exposure to conditions of increased stress, the inflammatory and pro-coagulant effects of endothelial cells are mediated by the NF-KB signaling [90], with downstream upregulation of target genes of adhesion molecules (VCAM-1, ICAM-1, E-selectin, PSelectin) and chemokines (monocyte chemoattractant protein (MCP)-1) [91-94]. Following that, the adhesion and transmigration of inflammatory cells (monocytes, T-lymphocytes) occur, with the ensuing activation of neutrophils leading to overexpression of inflammatory cytokines, chemokines, growth factors, and ROS. Moreover, NF- $\mathrm{kB}$ is responsible for the release of inflammatory mediators that modulate smooth muscle cell activation, further contributing to inflammation and atherosclerosis progression [95].

Concerning adhesion molecules specifically (Table 1), VCAM-1 has been considered an essential component of the endothelial activation cascade as it is involved in the selective adhesiveness of monocytes and lymphocytes, as they have been found to express the counterreceptor very late antigen (VLA)-4 $[96,97]$. ICAM- 1 is also implicated in the interaction between endothelial cells and monocytes through its ligands (lymphocyte function-associated antigen-1, macrophage- 1 antigen), by enabling the adhesion and migration of leukocytes [98]. Moving on to selectins (P-Selectin, E-Selectin, and L-Selectin), all of which can be found on the surface of endothelial cells, leukocytes, and platelets, their 
structure is based on an $\mathrm{N}$-terminal carbohydrate recognition domain, an epidermal growth factor-like domain, a varying number of short consensus repeats that have homology to complement regulatory domains (2, 6, and 9 within L-, E-, and P-selectin respectively), a transmembrane region, and a C-terminal cytoplasmatic tail [99]. The largest member of the family, P-Selectin, is situated on the membrane of the Weibel-Palade bodies of endothelial cells. The presence of its primary ligand (P-selectin glycoprotein ligand-1) on the surface of leukocytes indicates its role in leukocyte adhesion and rolling on endothelium, while available evidence points to an additional signaling role within the endothelium [99]. E-Selectin, whose upregulation is based on the NF- $\mathrm{KB}$ binding to regulatory domains in its promoter, has the capability of retarding leukocyte rolling leading to leukocyte arrest, making it pivotal in leukocyte trafficking and inflammatory responses [99]. The role of selectins in atherosclerotic diseases has been extensively investigated, with both molecules being present on endothelial cells of atherosclerotic plaques [100], while E-selectin or P-selectin deficient mice displayed attenuated atherosclerosis [101,102].Last but not least, MCP-1 has been the first reported inflammatory chemokine that is secreted from endothelial cells and monocytes, with its function consisting of leukocyte mobilization towards the subendothelium by binding on the CCR2 receptor, thus contributing to atherosclerosis [103]. Animal studies have shown that MCP-1 or CCR2 deficiency leads to lower lipid deposition and slowing of the atherosclerotic process [104,105], while its overexpression results in opposite effects with macrophage accumulation and atherosclerosis acceleration [106]. Moreover, another study has reported a role of MCP-1 on endothelial cell apoptosis [107]. Importantly, the role of adhesion molecules as markers of cardiovascular disease and incident cardiovascular risk has also been studied [108-114].

Table 1. Clinical implications of adhesion molecules involved in the interplay between endothelial dysfunction and inflammation.

\begin{tabular}{cccc}
\hline Adhesion Molecule & Ligand & Role & Clinical Significance \\
\hline ICAM-1 & $\begin{array}{c}\text { LFA-1 } \\
\text { Mac-1 }\end{array}$ & $\begin{array}{c}\text { Leukocyte } \\
\text { adhesion }\end{array}$ & $\begin{array}{c}\text { ICAM-1 correlates with the incidence of CAD and carotid atherosclerosis } \\
\text { independently of known cardiovascular risk factors [115]. }\end{array}$ \\
\hline VCAM-1 & VLA-4 & $\begin{array}{c}\text { Leukocyte } \\
\text { adhesion }\end{array}$ & $\begin{array}{c}\text { Baseline VCAM-1 is increased in initially healthy middle-aged men who } \\
\text { develop cardiovascular disease [116]. }\end{array}$ \\
\hline E-Selectin & ESL & $\begin{array}{c}\text { Leukocyte } \\
\text { adhesion }\end{array}$ & $\begin{array}{c}\text { E-Selectin correlates with the incidence of CAD and carotid atherosclerosis } \\
\text { independently of known cardiovascular risk factors [115]. }\end{array}$ \\
\hline P-Selectin & PSGL-1 & $\begin{array}{c}\text { Leukocyte } \\
\text { adhesion }\end{array}$ & $\begin{array}{c}\text { Elevated P-selectin levels predict early adverse events in patients with } \\
\text { presumed CAD [117]. }\end{array}$ \\
\hline MCP-1 & CCR2 & $\begin{array}{c}\text { Monocyte } \\
\text { chemotaxis }\end{array}$ & $\begin{array}{c}\text { Association of MCP-1 with risk of incident PAD and CAD independently } \\
\text { of traditional cardiovascular risk factors [118]. }\end{array}$ \\
\hline
\end{tabular}

ICAM-1: Intercellular adhesion molecule-1, VCAM-1: vascular cell adhesion molecule-1, MCP-1: monocyte chemoattractant protein-1, LFA-1: leukocyte function-associated antigen-1, VLA-4: very late antigen-4, ESL: E-selectin ligand, PSGL-1: P-selectin glycoprotein ligand-1, CCR2: C-C chemokine receptor type 2, CAD: coronary artery disease, PAD: peripheral arterial disease.

\subsection{The Pro-Inflammatory Effect of NOX}

NOX are the only family of enzymes primarily implicated in ROS generation, since other ROS regulators require an external ROS source to become involved in their formation. Therefore, their role in the initiation of the oxidative stress cascade is critical and depends upon the presence of cardiovascular risk factors. In such cases, NOX overproduction results in activation of inflammatory pathways together with eNOS uncoupling and scavenging of antioxidants [119].

From the four described NOX expressed in EC, NOX1, NOX2, and NOX5 are implicated in vascular diseases while an antiatherogenic role is speculated for NOX4 [119]. Even though NOX exert their pro-atherogenic effects via promotion of oxidative stress and impairment of NO bioavailability, recent reports have linked NOX-derived ROS to propagate NF- $\mathrm{kB}$ signaling and, consequently, the release of adhesion molecules and pro- 
inflammatory mediators [120]. Interestingly, exposure to oscillatory SS resulted in an upregulated expression of NOX2 via the action of sterol regulatory element binding protein 2, ultimately leading to NLRP3 inflammasome activation [121].

\subsection{Neutrophil Extracellular Traps}

Neutrophil extracellular traps (NETs), consisting of nuclear chromatin, histones, and proteins of various origins, have been recently attached to the inflammatory background of atherosclerotic cardiovascular diseases [122]. Excessive NET production may result in vascular leakage and endothelial-to-mesenchymal transition by degradation of VEcadherin [123], as well as in complement activation leading to endothelial injury [124].

Several pro-atherosclerotic conditions have been characterized by NETosis including hyperglycemia, dyslipidemia, and obesity. Starting with hyperglycemia, it has been proven that NET production is highly NADPH oxidase-dependent in the setting of DM [125], eventually resulting in endothelial injury via damage to the endothelial glycocalyx [126]. In cases of dyslipidemia, oxLDL may act on neutrophils to enhance NET formation, with the resulting product being able to propagate endothelial dysfunction [127]. Obesity is another condition with presumed NETosis owing to its pro-inflammatory actions and, as demonstrated in diet-induced obesity mouse models, the NET formation was assumed to be the orchestrator of endothelial dysfunction [128]. Studies assessing the association of NETs with endothelial function in humans are scarce, however, highlighting the continuous research that ought to be performed in this field.

\subsection{Shear Stress}

Endothelial cell regulation at the mechanical level is achieved via SS forces. In the setting of a laminar SS the beneficial, atheroprotective functions of endothelium remain intact (Figure 2). However, in areas of bifurcations, there is a differentiation of flow pattern towards turbulence, with an altered phenotype leading to increased adhesion of monocytes, proliferation, and apoptosis. It has been shown that the application of SS leads to the activation of multiple cell membrane mechanosensors such as integrins [129], G protein-coupled receptors [130], and endothelial glycocalyx [131], among others, with ensuing activation of downstream signaling pathways associated with functional gene expression. It is important to note that laminar SS application on cultured endothelial cells resulted in enhanced expression of eNOS [132], with Akt phosphorylation and subsequent eNOS phosphorylation at Ser 1177 being important for NO production [133].

In the presence of oscillating or low SS an increased burden of NF-KB molecules has been observed [134], pointing to a pro-inflammatory effect on the underlying endothelium which is potentially mediated by nuclear factor erythroid 2-related factor 2 (Nrf2) and Krüppel-like factor (KLF)-2 [135,136]. Moreover, low SS could be responsible for the disturbances of angiopoietin (Ang)/tyrosine kinase with immunoglobulin-like and EGFlike domains 1 (TIE1) axis via upregulation of the pro-inflammatory Ang2 in endothelial cells [137]. Recent evidence from omics studies of endothelial cells has proposed additional novel links between SS and genes involved in embryonic development. To begin with, the yes-associated protein (YAP)/TAZ pathway promotes JUN N-terminal kinase-mediated inflammation in conditions of low SS [138,139]. Twist-related protein 1 (TWIST1) is another molecule involved in developmental processes that has been investigated since it was found increased in aortic areas of low SS [140]. In a preclinical study, TWIST1 was induced in a GATA4-dependent manner after exposure to low SS with inflammation and endothelialto-mesenchymal transition processes being also promoted, thus leading to endothelial dysfunction [141]. Several other pathways (bone morphogenetic protein signaling, WNT signaling) have been implicated in the interaction between shear stress, inflammation, and endothelial function and merit further validation in animal studies [142,143].

Flow alterations have important implications in microRNA regulation. MicroRNAs are small non-coding RNA molecules consisting of 18-24 nucleotides that contribute to the regulation of numerous cellular functions such as multiplication, differentiation, apoptosis, 
and death, especially in situations of inflammation or trauma, via RNA interference and post-translational modification in gene expression. It is, therefore, expected that deregulated expression of epigenetics will affect inflammatory pathways and endothelial cell function. Starting with microRNA-126, which is believed to be a key regulator of vascular endothelial homeostasis and inflammation [144,145], even though early studies suggested a pro-atherogenic role, the latest evidence proposes an anti-inflammatory, endothelialprotective mechanism of action which is lost in conditions of disturbed flow [146-148]. MicroRNA 19a, a member of the microRNA-17 92a, is overexpressed in low SS and exerts pro-inflammatory effects by targeting HMGB1 [149]. MicroRNA-92 from the same cluster is also overexpressed in disturbed flow conditions and targets KLF2, KLF4, and the suppressor of cytokine signaling 5 (SOCS5), leading to endothelial inflammation and dysfunction [150]. Next, microRNA-663 overexpression under low SS conditions appears to induce endothelial inflammation with multiple targets involved [151]. MicroRNA-712, solely found in murine animal models, and its human homolog microRNA-205 are upregulated in situations of disturbed flow and are involved in endothelial cell inflammation mediated by the loss of tissue inhibitor of metalloproteinase-3 (TIMP3) expression [152]. MicroRNA-181 is also reduced under low SS conditions leading to NLR family pyrin domain containing 3 (NLRP3) inflammasome-dependent pyroptosis of endothelial cells [153].

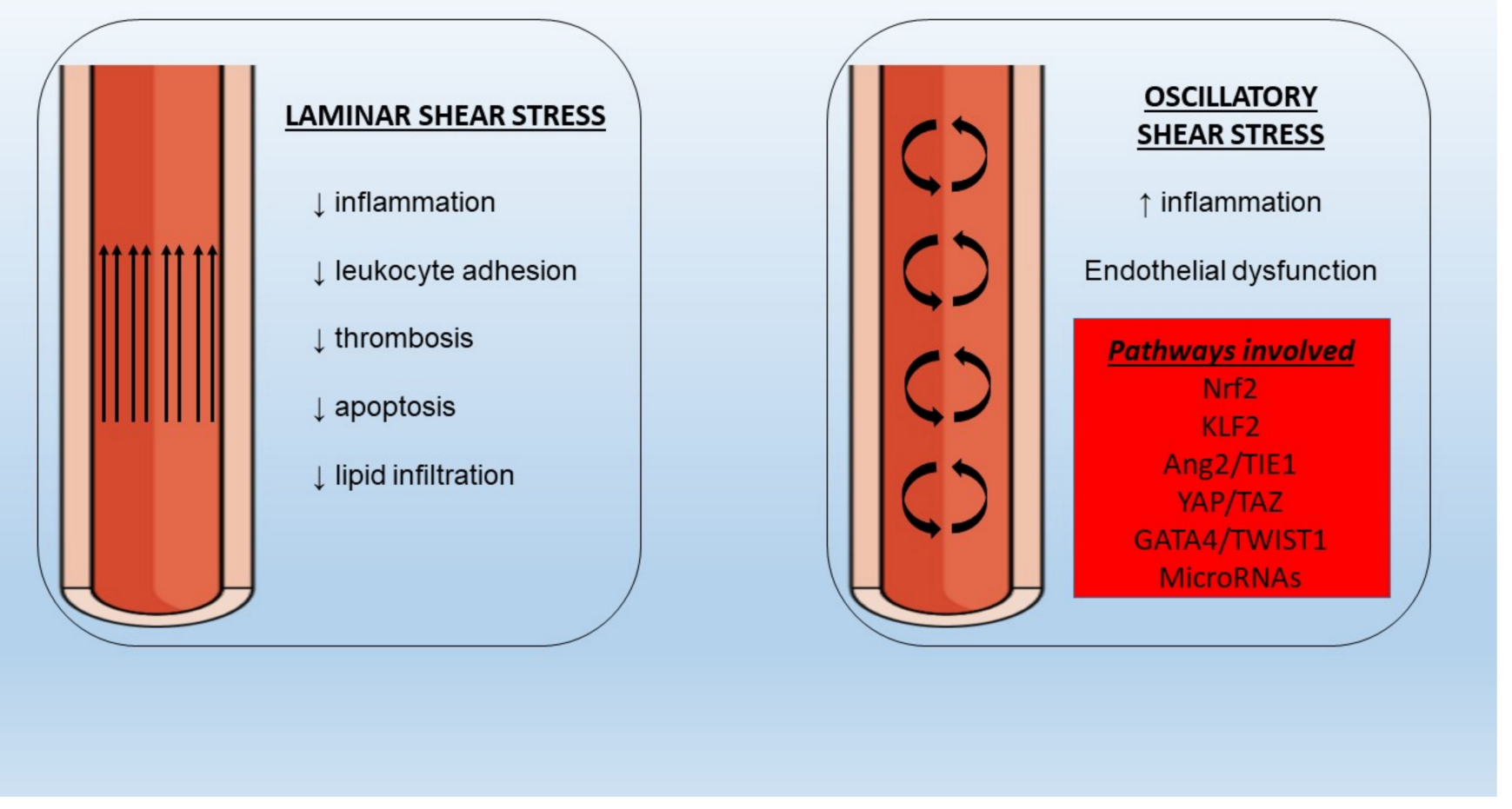

Figure 2. Different properties of laminar and oscillatory shear stress under normal and pathologic conditions with implications for inflammation and endothelial dysfunction. Nrf2: nuclear factor erythroid 2-related factor 2, KLF2: Krüppel-like factor-2, Ang2: angiopoietin-2, TIE1: tyrosine kinase with immunoglobulin-like and EGF-like domains-1, YAP: yes-associated protein, TWIST1: twist-related protein-1.

\subsection{Endothelial Dysfunction in Chronic Inflammatory Diseases}

An excess of adverse cardiovascular events in individuals with chronic autoimmune inflammatory diseases has been noted, with endothelial dysfunction potentially being the crucial link. Since these conditions are characterized by a significant inflammatory burden, the overexpression of inflammatory cytokines leads to increased oxidative stress and dyslipidemia, while the role of autoantibodies in the development of endothelial dysfunction remains to be elucidated [154]. 
Starting with rheumatoid arthritis, the presence of endothelial dysfunction is frequently present, as shown in a recent meta-analysis [155]. However, the correlations with disease duration, activity, and remission have been inconsistent [156]. In the case of systemic lupus erythematosus, which is also accompanied by increased cardiovascular disease rates [157], a higher prevalence of endothelial dysfunction has been observed the latest meta-analysis [158]. The presence of endothelial dysfunction has been described in patients with psoriasis, possibly due to the reduced NO bioavailability, which is correlated to symptom severity [159]. Importantly, the presence of impaired coronary endothelial function, assessed by positron emission tomography, in the above-mentioned inflammatory states was related to an increased rate of major adverse cardiovascular events [160]. Lastly, impaired endothelial function has been documented in patients with inflammatory bowel disease, correlated with disease activity in the majority of studies [161].

\section{A Link between Inflammation and Thrombosis in Endothelial Dysfunction}

Under healthy situations, the endothelium is capable of producing inhibitors of thrombin synthesis and activity, therefore maintaining the balance between coagulation and fibrinolysis. However, in situations of vascular injury and inflammation, the ensuing endothelial dysfunction and EC activation lead to a pro-thrombotic phenotype via the upregulation of coagulation factors. Activated EC can express active tissue factor on the cell surface thereby initiating the extrinsic pathway of coagulation [162], with experimental evidence highlighting the role of inflammatory mediators in this process, including TNF$\alpha$ [163], CD40 ligand [164], and other inflammatory cytokines [165]. The role of endothelial activation in the intrinsic pathway of coagulation is less clearly understood, with a recent report demonstrating the possible effect of inflammation on factor IX production following treatment of human umbilical vein endothelial cells with TNF [166].

Thrombomodulin is another mediator of thrombosis that is highly expressed in EC surface [167]. Its anti-thrombotic mechanism of action revolves around binding to thrombin, upregulation of activated protein $C$, and catalyzing thrombin inhibition by antithrombin $[168,169]$. In a recent study by Yang et al., Nur77 and Nor1 were identified as potential regulators of thrombomodulin expression [170] while inflammatory stimuli (CRP, oxLDL) have also been associated with downregulated expression and, thus, pro-thrombotic effects $[171,172]$.

Activation of endothelial cells also leads to platelet mobilization. In physiologic conditions, the vascular endothelium is responsible for inhibition of platelet aggregation and adhesion through the release of $\mathrm{NO}$ and prostaglandins among others. However, in conditions of endothelial activation and consequent vascular injury, there is a release of various mediators including von-Willebrand factor (vWF), P-selectin, and angiopoietin-2 from the Weibel-Palade bodies of endothelial cells. Regarding vWF, a crucial molecule associated with platelet activation and coagulation, it was recently shown that endothelialderived vWF was responsible for thrombus formation while platelet-derived vWF had only minor contributions [173], with similar findings observed concerning the vWF-dependent atherosclerotic process [174]. Inflammatory stimuli such as cytokines and superoxide anions lead to an increase in vWF $[175,176]$, which is also considered an acute phase reactant. Therefore, it has a dual role in thrombosis via the facilitation of platelet adhesion, aggregation, and prevention of factor VIII proteolytic degradation as well as in inflammation through leukocyte mobilization, complement activation, and NETosis [177].

Thrombosis as a result of endothelial dysfunction is also prevalent in severe bacterial and viral infections. In septic conditions, the increased concentration of inflammatory cytokines, reactive oxygen species, and NETs leads to a prothrombotic endothelial state and vascular leakage [178]. Consequently, the incident immunothrombosis may result in life-threatening sepsis-associated disseminated intravascular coagulation [179]. Immunothrombosis is especially relevant in the context of the ongoing coronavirus disease 2019 pandemic, where the endotheliitis from severe acute respiratory syndrome coronavirus 2 has been associated with an increased risk of thrombotic complications [180]. 


\section{Clinical Implications and Future Directions}

It is evident that despite optimal control of cardiovascular risk factors, a significant burden of cardiovascular mortality exists, with endothelial dysfunction being an important prognostic tool for incident adverse cardiovascular events [181,182]. As demonstrated in a study of patients with coronary artery disease (CAD) who underwent noninvasive evaluation of endothelial function with FMD of brachial artery, a significantly higher number of events was noted in those with consistently impaired endothelial function despite optimal medical therapy. Lifestyle modifications are the initial step towards the amelioration of endothelial function, as observed in several studies of exercise $[183,184]$, diet [185], and smoking cessation [186].

Concerning pharmacologic treatment, previous research has focused on evaluating the changes in endothelial function after treatment with statins. Their pleiotropic mechanism of action (anti-inflammatory, antioxidant) appears to improve endothelial dysfunction as observed in numerous studies $[187,188]$, independently from their lipid-lowering property [189]. Several other agents have been investigated (sodium-glucose cotransporter-2 inhibitors, glucagon-like peptide-1 receptor agonists, colchicine), albeit less extensively, with encouraging results according to the available preclinical and clinical evidence [190-194].

With a look to the future, it seems inevitable that precision medicine will become the mainstay of medical treatment since genetic and epigenetic variations between individuals could be the crucial contributing factor in atherosclerosis development. Studies have already evaluated the impact of such abnormalities in gene expression on dysfunctional endothelial phenotypes [195-198]. Furthermore, epigenetic manipulation via microRNA mimics or inhibitors is another appealing intervention under rigorous investigation in various diseases. In the context of inflammation and endothelial dysfunction, several microRNAs have been studied based on their action on various pathways (Table 2) and could end up being valuable diagnostic and therapeutic in the years to come.

Table 2. Favorable effects of microRNA modulation on endothelial dysfunction and inflammation.

\begin{tabular}{|c|c|c|c|}
\hline MicroRNA & Intervention & Target & Endothelial Effect \\
\hline 302c-3p [199] & $\uparrow$ & \multirow{2}{*}{$\begin{array}{l}\text { NLRP3 inflammasome } \\
\text { endothelin A receptor, NLRP3 } \\
\text { inflammasome }\end{array}$} & $\downarrow$ EC pyroptosis \\
\hline $1929-3 p[200]$ & $\uparrow$ & & $\downarrow$ EC injury and vascular remodeling \\
\hline $181 b-5 p[153]$ & $\uparrow$ & STAT3/NLRP3 inflammasome & $\downarrow$ EC pyroptosis \\
\hline $495[201]$ & $\uparrow$ & NLRP3 inflammasome & $\downarrow$ EC inflammation, apoptosis and $\uparrow$ EC proliferation \\
\hline $\begin{array}{c}20 \mathrm{~b}[202] \\
520 \mathrm{c}-3 \mathrm{p}[203]\end{array}$ & $\uparrow$ & TXNIP/NLRP3 & $\uparrow$ EC viability \\
\hline $520 c-3 p[203]$ & $\uparrow$ & NF-kB/Akt pathway & $\downarrow$ EC apoptosis \\
\hline $216 a[204]$ & $\downarrow$ & Smad7 & $\downarrow$ EC adhesive ability to monocytes \\
\hline $21[205]$ & $\downarrow$ & Smad7 & $\downarrow$ endothelial-to-mesenchymal transition \\
\hline $17-3 p[206]$ & $\uparrow$ & $\begin{array}{l}\text { NIK and IKK } \beta \text { binding } \\
\text { protein }\end{array}$ & $\downarrow$ monocyte adhesion to EC \\
\hline 217 [207] & $\uparrow$ & $\begin{array}{l}\text { Early growth response } \\
\text { protein-1 }\end{array}$ & $\begin{array}{c}\text { Relieve of EC growth inhibition, } \downarrow \text { endothelial } \\
\text { inflammation }\end{array}$ \\
\hline 200a [208] & $\uparrow$ & $\begin{array}{l}\text { EZH2-Mediated Methylation } \\
\text { of STAT3 }\end{array}$ & $\downarrow$ EC injury, apoptosis, and inflammation \\
\hline 200a [209] & $\uparrow$ & KEAP1/NRF2 & $\begin{array}{l}\downarrow \text { oxidative stress, inflammation, and endothelial } \\
\text { dysfunction }\end{array}$ \\
\hline $383[210]$ & $\downarrow$ & Sirtuin 1 & $\downarrow$ EC apoptosis and ROS production \\
\hline $34 a[211]$ & $\downarrow$ & Sirtuin 1 & $\begin{array}{r}\downarrow \text { EC inflammation, oxidative stress, and endothelial } \\
\text { dysfunction }\end{array}$ \\
\hline $34 \mathrm{a}[212]$ & $\downarrow$ & Sirtuin 1 & $\begin{array}{c}\text { Preservation of endothelium-dependent } \\
\text { vasorelaxation }\end{array}$ \\
\hline 204 [213] & $\downarrow$ & Sirtuin 1 & Mitigation of EC dysfunction \\
\hline $181 \mathrm{a} / 181 \mathrm{~b}[214]$ & $\uparrow$ & TAB2, NEMO & $\begin{array}{c}\downarrow \text { adhesion molecules expression and monocyte-EC } \\
\text { interaction }\end{array}$ \\
\hline $200 a / 200 b[215]$ & $\uparrow$ & $\begin{array}{l}\text { O-linked N-acetylglucosamine } \\
\text { transferase }\end{array}$ & $\downarrow$ EC inflammation and monocyte adhesion to EC \\
\hline
\end{tabular}

NLRP3: NLR family pyrin domain containing 3, EC: endothelial cell, STAT3: signal transducer and activator of transcription 3, TXNIP: thioredoxin interacting protein, NF-kB: nuclear factor kappa-light-chain-enhancer of activated B cells, Akt: protein kinase B, Smad7: SMAD family member 7, IKB $\alpha$ : inhibitor of kappa $\mathrm{B} \alpha$, EZH2: enhancer of zeste homolog 2, KEAP1:Kelch-like ECH-associated protein 1, NRF2: nuclear factor erythroid 2-related factor 2, ROS: reactive oxygen species, NEMO: NF-kB essential modulator. $\uparrow$ indicates agonism, $\downarrow$ indicates antagonism. 


\section{Conclusions}

Endothelial dysfunction is frequently mentioned in the initial steps of atherogenesis, promoted by the highly prevalent cardiovascular risk factors. Inflammation plays an important role in its development, with recent studies providing additional knowledge on the complex pathophysiology of endothelial dysfunction. Amelioration of endothelial function could represent an additional step in cardiovascular risk reduction at the early stages of atherogenesis, with the role of genetic and epigenetic manipulation being under rigorous investigation.

Author Contributions: All authors were involved in the drafting and critical revision of the manuscript. All authors have read and agreed to the published version of the manuscript.

Funding: This research received no external funding.

Institutional Review Board Statement: Not applicable.

Informed Consent Statement: Not applicable.

Conflicts of Interest: The authors declare no conflict of interest.

\section{References}

1. Yeboah, J.; Folsom, A.R.; Burke, G.L.; Johnson, C.; Polak, J.F.; Post, W.; Lima, J.A.; Crouse, J.R.; Herrington, D.M. Predictive Value of Brachial Flow-Mediated Dilation for Incident Cardiovascular Events in a Population-Based Study. Circulation 2009, 120, 502-509. [CrossRef] [PubMed]

2. Shechter, M.; Shechter, A.; Koren-Morag, N.; Feinberg, M.S.; Hiersch, L. Usefulness of Brachial Artery Flow-Mediated Dilation to Predict Long-Term Cardiovascular Events in Subjects without Heart Disease. Am. J. Cardiol. 2014, 113, 162-167. [CrossRef] [PubMed]

3. Rubinshtein, R.; Kuvin, J.T.; Soffler, M.; Lennon, R.J.; Lavi, S.; Nelson, R.E.; Pumper, G.M.; Lerman, L.O.; Lerman, A. Assessment of endothelial function by non-invasive peripheral arterial tonometry predicts late cardiovascular adverse events. Eur. Heart $\mathrm{J}$. 2010, 31, 1142-1148. [CrossRef] [PubMed]

4. Yeboah, J.; Crouse, J.R.; Hsu, F.-C.; Burke, G.L.; Herrington, D.M. Brachial Flow-Mediated Dilation Predicts Incident Cardiovascular Events in Older Adults. Circulation 2007, 115, 2390-2397. [CrossRef] [PubMed]

5. Tousoulis, D.; Antoniades, C.; Stefanadis, C. Evaluating endothelial function in humans: A guide to invasive and non-invasive techniques. Heart 2005, 91, 553-558. [CrossRef]

6. Alexander, Y.; Osto, E.; Schmidt-Trucksäss, A.; Shechter, M.; Trifunovic, D.; Duncker, D.J.; Aboyans, V.; Bäck, M.; Badimon, L.; Cosentino, F.; et al. Endothelial function in cardiovascular medicine: A consensus paper of the European Society of Cardiology Working Groups on Atherosclerosis and Vascular Biology, Aorta and Peripheral Vascular Diseases, Coronary Pathophysiology and Microcirculation, and Thrombosis. Cardiovasc. Res. 2021, 117, 29-42. [CrossRef]

7. Moncada, S.; Higgs, E.; Vane, J. Human Arterial and Venous Tissues Generate Prostacyclin (Prostaglandin X), a Potent Inhibitor of Platelet Aggregation. Lancet 1977, 309, 18-21. [CrossRef]

8. Weksler, B.B.; Marcus, A.J.; Jaffe, E.A. Synthesis of prostaglandin I2 (prostacyclin) by cultured human and bovine endothelial cells. Proc. Natl. Acad. Sci. USA 1977, 74, 3922-3926. [CrossRef]

9. Furchgott, R.F.; Zawadzki, J.V. The obligatory role of endothelial cells in the relaxation of arterial smooth muscle by acetylcholine. Nature 1980, 288, 373-376. [CrossRef] [PubMed]

10. Krüger-Genge, A.; Blocki, A.; Franke, R.-P.; Jung, F. Vascular Endothelial Cell Biology: An Update. Int. J. Mol. Sci. 2019, $20,4411$. [CrossRef] [PubMed]

11. Tousoulis, D.; Kampoli, A.-M.; Papageorgiou, N.; Stefanadis, C. The Role of Nitric Oxide on Endothelial Function. Curr. Vasc. Pharmacol. 2012, 10, 4-18. [CrossRef] [PubMed]

12. Griffith, T.M.; Edwards, D.; Lewis, M.J.; Newby, A.C.; Henderson, A.H. The nature of endothelium-derived vascular relaxant factor. Nature 1984, 308, 645-647. [CrossRef] [PubMed]

13. Di Lorenzo, A.; Lin, M.I.; Murata, T.; Landskroner-Eiger, S.; Schleicher, M.; Kothiya, M.; Iwakiri, Y.; Yu, J.; Huang, P.; Sessa, W.C. eNOS derived nitric oxide regulates endothelial barrier function via VE cadherin and Rho GTPases. J. Cell Sci. 2013, 126, 5541-5552. [CrossRef] [PubMed]

14. Jourd'Heuil, D.; Jourd'Heuil, F.L.; Kutchukian, P.S.; Musah, R.A.; Wink, D.A.; Grisham, M.B. Reaction of Superoxide and Nitric Oxide with Peroxynitrite. Implications for peroxynitrite-mediated oxidation reactions in vivo. J. Biol. Chem. 2001, 276, 28799-28805. [CrossRef]

15. Selemidis, S.; Dusting, G.J.; Peshavariya, H.; Kemp-Harper, B.K.; Drummond, G. Nitric oxide suppresses NADPH oxidasedependent superoxide production by S-nitrosylation in human endothelial cells. Cardiovasc. Res. 2007, 75, 349-358. [CrossRef] [PubMed] 
16. Flammer, A.; Anderson, T.; Celermajer, D.; Creager, M.A.; Deanfield, J.; Ganz, P.; Hamburg, N.; Lüscher, T.F.; Shechter, M.; Taddei, S.; et al. The Assessment of Endothelial Function. Circulation 2012, 126, 753-767. [CrossRef]

17. Flammer, A.J.; Lüscher, T.F. Human endothelial dysfunction: EDRFs. Pflügers Arch. Eur. J. Physiol. 2010, 459, 1005-1013. [CrossRef]

18. Petrie, J.R.; Ueda, S.; Morris, A.D.; Murray, L.S.; Elliott, H.L.; Connell, J.M.C. How reproducible is bilateral forearm plethysmography? Br. J. Clin. Pharmacol. 1998, 45, 131-139. [CrossRef]

19. Thijssen, D.H.J.; Bruno, R.M.; Van Mil, A.C.C.M.; Holder, S.M.; Faita, F.; Greyling, A.; Zock, P.L.; Taddei, S.; Deanfield, J.; Luscher, T.; et al. Expert consensus and evidence-based recommendations for the assessment of flow-mediated dilation in humans. Eur. Heart J. 2019, 40, 2534-2547. [CrossRef]

20. Greyling, A.; Van Mil, A.C.; Zock, P.L.; Green, D.J.; Ghiadoni, L.; Thijssen, D.H. Adherence to guidelines strongly improves reproducibility of brachial artery flow-mediated dilation. Atherosclerosis 2016, 248, 196-202. [CrossRef]

21. Takishima, I.; Nakamura, T.; Hirano, M.; Kitta, Y.; Kobayashi, T.; Fujioka, D.; Saito, Y.; Watanabe, K.; Watanabe, Y.; Mishina, H.; et al. Predictive value of serial assessment of endothelial function in chronic heart failure. Int. J. Cardiol. 2012, 158, 417-422. [CrossRef]

22. Kitta, Y.; Obata, J.-E.; Nakamura, T.; Hirano, M.; Kodama, Y.; Fujioka, D.; Saito, Y.; Kawabata, K.-I.; Sano, K.; Kobayashi, T.; et al. Persistent Impairment of Endothelial Vasomotor Function Has a Negative Impact on Outcome in Patients with Coronary Artery Disease. J. Am. Coll. Cardiol. 2009, 53, 323-330. [CrossRef]

23. Dimitropoulos, S.; Mystakidi, V.C.; Oikonomou, E.; Siasos, G.; Tsigkou, V.; Athanasiou, D.; Gouliopoulos, N.; Bletsa, E.; Kalampogias, A.; Charalambous, G.; et al. Association of Soluble Suppression of Tumorigenesis-2 (ST2) with Endothelial Function in Patients with Ischemic Heart Failure. Int. J. Mol. Sci. 2020, 21, 9385. [CrossRef]

24. Mourouzis, K.; Siasos, G.; Oikonomou, E.; Zaromitidou, M.; Tsigkou, V.; Antonopoulos, A.; Bletsa, E.; Stampouloglou, P.; Vlasis, K.; Vavuranakis, M.; et al. Lipoprotein-associated phospholipase A2 levels, endothelial dysfunction and arterial stiffness in patients with stable coronary artery disease. Lipids Health Dis. 2021, 20, 1-9. [CrossRef] [PubMed]

25. Kuvin, J.T.; Patel, A.; A Sliney, K.; Pandian, N.G.; Sheffy, J.; Schnall, R.P.; Karas, R.H.; E Udelson, J. Assessment of peripheral vascular endothelial function with finger arterial pulse wave amplitude. Am. Heart J. 2003, 146, 168-174. [CrossRef]

26. Nohria, A.; Gerhard-Herman, M.; Creager, M.A.; Hurley, S.; Mitra, D.; Ganz, P. Role of nitric oxide in the regulation of digital pulse volume amplitude in humans. J. Appl. Physiol. 2006, 101, 545-548. [CrossRef] [PubMed]

27. Bonetti, P.O.; Pumper, G.M.; Higano, S.T.; Holmes, D.R.; Kuvin, J.T.; Lerman, A. Noninvasive identification of patients with early coronary atherosclerosis by assessment of digital reactive hyperemia. J. Am. Coll. Cardiol. 2004, 44, 2137-2141. [CrossRef] [PubMed]

28. Hamburg, N.M.; Palmisano, J.; Larson, M.; Sullivan, L.; Lehman, B.T.; Vasan, R.S.; Levy, D.; Mitchell, G.F.; Vita, J.; Benjamin, E. Relation of Brachial and Digital Measures of Vascular Function in the Community: The Framingham heart study. Hypertension 2011, 57, 390-396. [CrossRef]

29. Schnabel, R.B.; Schulz, A.; Wild, P.S.; Sinning, C.R.; Wilde, S.; Eleftheriadis, M.; Herkenhoff, S.; Zeller, T.; Lubos, E.; Lackner, K.J.; et al. Noninvasive Vascular Function Measurement in the Community. Circ. Cardiovasc. Imaging 2011, 4, 371-380. [CrossRef]

30. Sharifizad, M.; Witkowska, K.J.; Aschinger, G.C.; Sapeta, S.; Rauch, A.; Schmidl, D.; Werkmeister, R.M.; Garhöfer, G.; Schmetterer, L. Factors Determining Flicker-Induced Retinal Vasodilation in Healthy Subjects. Investig. Opthalmol. Vis. Sci. 2016, 57, $3306-3312$. [CrossRef]

31. Nguyen, T.T.; Kawasaki, R.; Wang, J.J.; Kreis, A.J.; Shaw, J.; Vilser, W.; Wong, T.Y. Flicker Light-Induced Retinal Vasodilation in Diabetes and Diabetic Retinopathy. Diabetes Care 2009, 32, 2075-2080. [CrossRef]

32. Patel, S.R.; Bellary, S.; Karimzad, S.; Gherghel, D. Overweight status is associated with extensive signs of microvascular dysfunction and cardiovascular risk. Sci. Rep. 2016, 6, 32282. [CrossRef] [PubMed]

33. Nägele, M.P.; Barthelmes, J.; Ludovici, V.; Cantatore, S.; Von Eckardstein, A.; Enseleit, F.; Lüscher, T.F.; Ruschitzka, F.; Sudano, I.; Flammer, A.J. Retinal microvascular dysfunction in heart failure. Eur. Heart J. 2018, 39, 47-56. [CrossRef] [PubMed]

34. Anna, M.; Ewa, P.-S.; Katarzyna, B.; Anna, S.; Krzysztof, S.; Piotr, K.M.; Bogusław, M. Correlation between Flicker-Induced Retinal Vessel Vasodilatation and Plasma Biomarkers of Endothelial Dysfunction in Hypertensive Patients. Curr. Eye Res. 2018, 43, 128-134. [CrossRef]

35. Leite, A.R.; Borges-Canha, M.; Cardoso, R.; Neves, J.S.; Castro-Ferreira, R.; Leite-Moreira, A. Novel Biomarkers for Evaluation of Endothelial Dysfunction. Angiology 2020, 71, 397-410. [CrossRef]

36. Balta, S.; Mikhailidis, D.P.; Demirkol, S.; Ozturk, C.; Celik, T.; Iyisoy, A. Endocan: A novel inflammatory indicator in cardiovascular disease? Atherosclerosis 2015, 243, 339-343. [CrossRef]

37. Liaudet, L.; Vassalli, G.; Pacher, P. Role of peroxynitrite in the redox regulation of cell signal transduction pathways. Front. Biosci. Landmark 2009, 14, 4809-4814. [CrossRef]

38. Diers, A.R.; Broniowska, K.A.; Hogg, N. Nitrosative stress and redox-cycling agents synergize to cause mitochondrial dysfunction and cell death in endothelial cells. Redox Biol. 2013, 1, 1-7. [CrossRef] [PubMed]

39. Alp, N.J.; Channon, K. Regulation of Endothelial Nitric Oxide Synthase by Tetrahydrobiopterin in Vascular Disease. Arterioscler. Thromb. Vasc. Biol. 2004, 24, 413-420. [CrossRef] [PubMed]

40. Shi, W.; Meininger, C.J.; Haynes, T.E.; Hatakeyama, K.; Wu, G. Regulation of Tetrahydrobiopterin Synthesis and Bioavailability in Endothelial Cells. Cell Biochem. Biophys. 2004, 41, 415-434. [CrossRef] 
41. Chalupsky, K.; Cai, H. Endothelial dihydrofolate reductase: Critical for nitric oxide bioavailability and role in angiotensin II uncoupling of endothelial nitric oxide synthase. Proc. Natl. Acad. Sci. USA 2005, 102, 9056-9061. [CrossRef]

42. Landmesser, U.; Dikalov, S.; Price, S.R.; McCann, L.; Fukai, T.; Holland, S.M.; Mitch, W.E.; Harrison, D.G. Oxidation of tetrahydrobiopterin leads to uncoupling of endothelial cell nitric oxide synthase in hypertension. J. Clin. Investig. 2003, 111, 1201-1209. [CrossRef] [PubMed]

43. Antoniades, C.; Shirodaria, C.; Leeson, P.; Antonopoulos, A.; Warrick, N.; Van-Assche, T.; Cunnington, C.; Tousoulis, D.; Pillai, R.; Ratnatunga, C.; et al. Association of plasma asymmetrical dimethylarginine (ADMA) with elevated vascular superoxide production and endothelial nitric oxide synthase uncoupling: Implications for endothelial function in human atherosclerosis. Eur. Heart J. 2009, 30, 1142-1150. [CrossRef] [PubMed]

44. Bedford, M.T.; Clarke, S.G. Protein Arginine Methylation in Mammals: Who, What, and Why. Mol. Cell 2009, 33, 1-13. [CrossRef] [PubMed]

45. Mohan, S.; Fung, H.-L. Mechanism of Cellular Oxidation Stress Induced by Asymmetric Dimethylarginine. Int. J. Mol. Sci. 2012, 13, 7521-7531. [CrossRef] [PubMed]

46. Antoniades, C.; Demosthenous, M.; Tousoulis, D.; Antonopoulos, A.; Vlachopoulos, C.; Toutouza, M.; Marinou, K.; Bakogiannis, C.; Mavragani, K.; Lazaros, G.; et al. Role of Asymmetrical Dimethylarginine in Inflammation-Induced Endothelial Dysfunction in Human Atherosclerosis. Hypertension 2011, 58, 93-98. [CrossRef] [PubMed]

47. Zuccala, A.; Fiorenza, S.; Rapana, R.; Santoro, A. Hypertension, atherosclerosis and kidney. G. Ital. Nefrol. 2005, 22 (Suppl. 31), S9-S14.

48. Carnevale, R.; Sciarretta, S.; Violi, F.; Nocella, C.; Loffredo, L.; Perri, L.; Peruzzi, M.; Marullo, A.G.; De Falco, E.; Chimenti, I.; et al. Acute Impact of Tobacco vs Electronic Cigarette Smoking on Oxidative Stress and Vascular Function. Chest 2016, 150, 606-612. [CrossRef]

49. Sugiura, T.; Dohi, Y.; Takase, H.; Yamashita, S.; Fujii, S.; Ohte, N. Oxidative Stress is Closely Associated with Increased Arterial Stiffness, Especially in Aged Male Smokers without Previous Cardiovascular Events: A Cross-Sectional Study. J. Atheroscler. Thromb. 2017, 24, 1186-1198. [CrossRef]

50. Vlachopoulos, C.; Aznaouridis, K.; Bratsas, A.; Ioakeimidis, N.; Dima, I.; Xaplanteris, P.; Stefanadis, C.; Tousoulis, D. Arterial stiffening and systemic endothelial activation induced by smoking: The role of COX-1 and COX-2. Int. J. Cardiol. 2015, 189, 293-298. [CrossRef]

51. Abdelghany, T.M.; Ismail, R.S.; Mansoor, F.A.; Zweier, J.R.; Lowe, F.; Zweier, J.L. Cigarette smoke constituents cause endothelial nitric oxide synthase dysfunction and uncoupling due to depletion of tetrahydrobiopterin with degradation of GTP cyclohydrolase. Nitric Oxide 2018, 76, 113-121. [CrossRef]

52. Halvorsen, B.; Sagen, L.E.; Ueland, T.; Aukrust, P.; Tonstad, S. Effect of smoking cessation on markers of inflammation and endothelial cell activation among individuals with high risk for cardiovascular disease. Scand. J. Clin. Lab. Investig. 2007, 67, 604-611. [CrossRef]

53. Tsai, J.-S.; Guo, F.-R.; Chen, S.-C.; Lue, B.-H.; Lee, L.-T.; Huang, K.-C.; Chen, C.-Y.; Hung, S.-H.; Chuang, L.-M.; Chen, C.-Y. Changes of serum adiponectin and soluble intercellular adhesion molecule-1 concentrations after smoking cessation. Clin. Chem. Lab. Med. 2012, 50, 1063-1069. [CrossRef] [PubMed]

54. Delgado, G.E.; Krämer, B.K.; Siekmeier, R.; Yazdani, B.; März, W.; Leipe, J.; Kleber, M.E. Influence of smoking and smoking cessation on biomarkers of endothelial function and their association with mortality. Atherosclerosis 2020, 292, 52-59. [CrossRef]

55. Saeedi, P.; Petersohn, I.; Salpea, P.; Malanda, B.; Karuranga, S.; Unwin, N.; Colagiuri, S.; Guariguata, L.; Motala, A.A.; Ogurtsova, K.; et al. Global and regional diabetes prevalence estimates for 2019 and projections for 2030 and 2045: Results from the International Diabetes Federation Diabetes Atlas, 9th edition. Diabetes Res. Clin. Pract. 2019, 157, 107843. [CrossRef]

56. Brownlee, M. The Pathobiology of Diabetic Complications: A Unifying Mechanism. Diabetes 2005, 54, 1615-1625. [CrossRef]

57. Asmat, U.; Abad, K.; Ismail, K. Diabetes mellitus and oxidative stress-A concise review. Saudi Pharm. J. 2016, $24,547-553$. [CrossRef]

58. Brandes, R. Endothelial Dysfunction and Hypertension. Hypertension 2014, 64, 924-928. [CrossRef] [PubMed]

59. Perticone, F.; Ceravolo, R.; Pujia, A.; Ventura, G.; Iacopino, S.; Scozzafava, A.; Ferraro, A.; Chello, M.; Mastroroberto, P.; Verdecchia, P.; et al. Prognostic Significance of Endothelial Dysfunction in Hypertensive Patients. Circulation 2001, 104, 191-196. [CrossRef] [PubMed]

60. Schulz, E.; Gori, T.; Münzel, T. Oxidative stress and endothelial dysfunction in hypertension. Hypertens. Res. 2011, 34, 665-673. [CrossRef] [PubMed]

61. Perticone, F.; Sciacqua, A.; Maio, R.; Perticone, M.; Maas, R.; Boger, R.H.; Tripepi, G.; Sesti, G.; Zoccali, C. Asymmetric Dimethylarginine, L-Arginine, and Endothelial Dysfunction in Essential Hypertension. J. Am. Coll. Cardiol. 2005, 46, 518-523. [CrossRef]

62. Böhm, F.; Pernow, J. The importance of endothelin-1 for vascular dysfunction in cardiovascular disease. Cardiovasc. Res. 2007, 76, 8-18. [CrossRef] [PubMed]

63. Dijkhorst-Oei, L.T.; Stroes, E.S.G.; Koomans, H.A.; Rabelink, T.J. Acute Simultaneous Stimulation of Nitric Oxide and Oxygen Radicals by Angiotensin II in Humans in Vivo. J. Cardiovasc. Pharmacol. 1999, 33, 420-424. [CrossRef] 
64. Gliozzi, M.; Scicchitano, M.; Bosco, F.; Musolino, V.; Carresi, C.; Scarano, F.; Maiuolo, J.; Nucera, S.; Maretta, A.; Paone, S.; et al. Modulation of Nitric Oxide Synthases by Oxidized LDLs: Role in Vascular Inflammation and Atherosclerosis Development. Int. J. Mol. Sci. 2019, 20, 3294. [CrossRef] [PubMed]

65. Valente, A.J.; Irimpen, A.M.; Siebenlist, U.; Chandrasekar, B. OxLDL induces endothelial dysfunction and death via TRAF3IP2: Inhibition by HDL3 and AMPK activators. Free Radic. Biol. Med. 2014, 70, 117-128. [CrossRef]

66. Dallinga-Thie, G.M.; Kroon, J.; Schnitzler, J.G. The Role of (Modified) Lipoproteins in Vascular Function: A Duet Between Monocytes and the Endothelium. Curr. Med. Chem. 2019, 26, 1594-1609. [CrossRef]

67. Pober, J.S.; Cotran, R.S. Cytokines and endothelial cell biology. Physiol. Rev. 1990, 70, 427-451. [CrossRef] [PubMed]

68. Gong, T.; Liu, L.; Jiang, W.; Zhou, R. DAMP-sensing receptors in sterile inflammation and inflammatory diseases. Nat. Rev. Immunol. 2020, 20, 95-112. [CrossRef]

69. Cao, X. Self-regulation and cross-regulation of pattern-recognition receptor signalling in health and disease. Nat. Rev. Immunol. 2015, 16, 35-50. [CrossRef]

70. Han, J.; Ulevitch, R.J. Limiting inflammatory responses during activation of innate immunity. Nat. Immunol. 2005, 6, 1198-1205. [CrossRef]

71. Kawasaki, T.; Kawai, T. Toll-Like Receptor Signaling Pathways. Front. Immunol. 2014, 5, 461. [CrossRef]

72. Zhu, Z.; Peng, X.; Li, X.; Tu, T.; Yang, H.; Teng, S.; Zhang, W.; Xing, Z.; Tang, J.; Hu, X.; et al. HMGB1 impairs endotheliumdependent relaxation in diabetes through TLR4/eNOS pathway. FASEB J. 2020, 34, 8641-8652. [CrossRef]

73. Chen, L.; Zhu, H.; Su, S.; Harshfield, G.; Sullivan, J.; Webb, C.; Blumenthal, J.A.; Wang, X.; Huang, Y.; Treiber, F.A.; et al. High-Mobility Group Box-1 Is Associated with Obesity, Inflammation, and Subclinical Cardiovascular Risk among Young Adults: A Longitudinal Cohort Study. Arterioscler. Thromb. Vasc. Biol. 2020, 40, 2776-2784. [CrossRef]

74. Behl, T.; Sharma, E.; Sehgal, A.; Kaur, I.; Kumar, A.; Arora, R.; Pal, G.; Kakkar, M.; Kumar, R.; Bungau, S. Expatiating the molecular approaches of HMGB1 in diabetes mellitus: Highlighting signalling pathways via RAGE and TLRs. Mol. Biol. Rep. 2021, 48, 1869-1881. [CrossRef]

75. Singh, G.B.; Zhang, Y.; Boini, K.M.; Koka, S. High Mobility Group Box 1 Mediates TMAO-Induced Endothelial Dysfunction. Int. J. Mol. Sci. 2019, 20, 3570. [CrossRef]

76. Hernanz, R.; Martínez-Revelles, S.; Palacios, R.; Martín, A.; Cachofeiro, V.; Aguado, A.; García-Redondo, L.; Barrús, M.T.; De Batista, P.R.; Briones, A.M.; et al. Toll-like receptor 4 contributes to vascular remodelling and endothelial dysfunction in angiotensin II-induced hypertension. Br. J. Pharmacol. 2015, 172, 3159-3176. [CrossRef]

77. Martinon, F.; Burns, K.; Tschopp, J. The Inflammasome: A molecular platform triggering activation of inflammatory caspases and processing of proIL- $\beta$. Mol. Cell 2002, 10, 417-426. [CrossRef]

78. Franchi, L.; Eigenbrod, T.; Muñoz-Planillo, R.; Nuñez, G. The inflammasome: A caspase-1-activation platform that regulates immune responses and disease pathogenesis. Nat. Immunol. 2009, 10, 241-247. [CrossRef]

79. Loukovaara, S.; Piippo, N.; Kinnunen, K.; Hytti, M.; Kaarniranta, K.; Kauppinen, A. NLRP3 inflammasome activation is associated with proliferative diabetic retinopathy. Acta Ophthalmol. 2017, 95, 803-808. [CrossRef]

80. De Miguel, C.; Pelegrín, P.; Baroja-Mazo, A.; Cuevas, S. Emerging Role of the Inflammasome and Pyroptosis in Hypertension. Int. J. Mol. Sci. 2021, 22, 1064. [CrossRef]

81. Rheinheimer, J.; de Souza, B.M.; Cardoso, N.S.; Bauer, A.C.; Crispim, D. Current role of the NLRP3 inflammasome on obesity and insulin resistance: A systematic review. Metabolism 2017, 74, 1-9. [CrossRef]

82. Oikonomou, E.; Leopoulou, M.; Theofilis, P.; Antonopoulos, A.; Siasos, G.; Latsios, G.; Mystakidi, V.C.; Antoniades, C.; Tousoulis, D. A link between inflammation and thrombosis in atherosclerotic cardiovascular diseases: Clinical and therapeutic implications. Atherosclerosis 2020, 309, 16-26. [CrossRef]

83. Yang, Y.; Wang, H.; Kouadir, M.; Song, H.; Shi, F. Recent advances in the mechanisms of NLRP3 inflammasome activation and its inhibitors. Cell Death Dis. 2019, 10, 128. [CrossRef]

84. Kayagaki, N.; Wong, M.T.; Stowe, I.B.; Ramani, S.R.; Gonzalez, L.C.; Akashi-Takamura, S.; Miyake, K.; Zhang, J.; Lee, W.P.; Muszyński, A.; et al. Noncanonical Inflammasome Activation by Intracellular LPS Independent of TLR4. Science 2013, 341, 1246-1249. [CrossRef]

85. Gaidt, M.M.; Ebert, T.S.; Chauhan, D.; Schmidt, T.; Schmid-Burgk, J.; Rapino, F.; Robertson, A.; Cooper, M.; Graf, T.; Hornung, V. Human Monocytes Engage an Alternative Inflammasome Pathway. Immunity 2016, 44, 833-846. [CrossRef]

86. Naik, E.; Dixit, V.M. Mitochondrial reactive oxygen species drive proinflammatory cytokine production. J. Exp. Med. 2011, 208, 417-420. [CrossRef] [PubMed]

87. Abderrazak, A.; Syrovets, T.; Couchie, D.; El Hadri, K.; Friguet, B.; Simmet, T.; Rouis, M. NLRP3 inflammasome: From a danger signal sensor to a regulatory node of oxidative stress and inflammatory diseases. Redox Biol. 2015, 4, 296-307. [CrossRef] [PubMed]

88. Galea, J.; Armstrong, J.; Gadsdon, P.; Holden, H.; Francis, S.; Holt, C.M. Interleukin-1 $\beta$ in Coronary Arteries of Patients With Ischemic Heart Disease. Arterioscler. Thromb. Vasc. Biol. 1996, 16, 1000-1006. [CrossRef]

89. Mallat, Z.; Corbaz, A.; Scoazec, A.; Besnard, S.; Lesèche, G.; Chvatchko, Y.; Tedgui, A. Expression of Interleukin-18 in Human Atherosclerotic Plaques and Relation to Plaque Instability. Circulation 2001, 104, 1598-1603. [CrossRef]

90. Rahman, A.; Fazal, F. Blocking NF- B: An Inflammatory Issue. Proc. Am. Thorac. Soc. 2011, 8, 497-503. [CrossRef] 
91. Rollins, B.J.; Yoshimura, T.; Leonard, E.J.; Pober, J.S. Cytokine-activated human endothelial cells synthesize and secrete a monocyte chemoattractant, MCP-1/JE. Am. J. Pathol. 1990, 136, 1229-1233.

92. Turner, M.D.; Nedjai, B.; Hurst, T.; Pennington, D.J. Cytokines and chemokines: At the crossroads of cell signalling and inflammatory disease. Biochim. Biophys. Acta 2014, 1843, 2563-2582. [CrossRef]

93. Sprague, A.H.; Khalil, R.A. Inflammatory cytokines in vascular dysfunction and vascular disease. Biochem. Pharmacol. 2009, 78, 539-552. [CrossRef] [PubMed]

94. Xue, J.; Thippegowda, P.B.; Hu, G.; Bachmaier, K.; Christman, J.W.; Malik, A.B.; Tiruppathi, C. NF-kB regulates thrombin-induced ICAM-1 gene expression in cooperation with NFAT by binding to the intronic NF-kB site in the ICAM-1 gene. Physiol. Genomics 2009, 38, 42-53. [CrossRef] [PubMed]

95. Mehrhof, F.B.; Schmidt-Ullrich, R.; Dietz, R.; Scheidereit, C. Regulation of Vascular Smooth Muscle Cell Proliferation: Role of NF-кB Revisited. Circ. Res. 2005, 96, 958-964. [CrossRef] [PubMed]

96. Chakraborty, S.; Hu, S.-Y.; Wu, S.-H.; Karmenyan, A.; Chiou, A. The Interaction Affinity between Vascular Cell Adhesion Molecule1 (VCAM-1) and Very Late Antigen-4 (VLA-4) Analyzed by Quantitative FRET. PLoS ONE 2015, 10, e0121399. [CrossRef]

97. Imai, Y.; Shimaoka, M.; Kurokawa, M. Essential roles of VLA-4 in the hematopoietic system. Int. J. Hematol. 2010, 91, 569-575. [CrossRef]

98. Frank, P.G.; Lisanti, M.P. ICAM-1: Role in inflammation and in the regulation of vascular permeability. Am. J. Physiol. Heart Circ. Physiol. 2008, 295, H926-H927. [CrossRef]

99. Silva, M.; Videira, P.A.; Sackstein, R. E-Selectin Ligands in the Human Mononuclear Phagocyte System: Implications for Infection, Inflammation, and Immunotherapy. Front. Immunol. 2018, 8, 1878. [CrossRef]

100. Davies, P.M.J.; Gordon, J.L.; Gearing, A.J.H.; Pigott, R.; Woolf, N.; Katz, D.; Kyriakopoulos, A. The expression of the adhesion molecules ICAM-1, VCAM-1, PECAM, and E-selectin in human atherosclerosis. J. Pathol. 1993, 171, 223-229. [CrossRef]

101. Collins, R.G.; Velji, R.; Guevara, N.V.; Hicks, M.J.; Chan, L.; Beaudet, A.L. P-Selectin or Intercellular Adhesion Molecule (Icam)-1 Deficiency Substantially Protects against Atherosclerosis in Apolipoprotein E-Deficient Mice. J. Exp. Med. 2000, 191, 189-194. [CrossRef] [PubMed]

102. Dong, Z.M.; Chapman, S.M.; A Brown, A.; Frenette, P.S.; Hynes, R.O.; Wagner, D.D. The combined role of P- and E-selectins in atherosclerosis. J. Clin. Investig. 1998, 102, 145-152. [CrossRef]

103. Niu, J.; Kolattukudy, P.E. Role of MCP-1 in cardiovascular disease: Molecular mechanisms and clinical implications. Clin. Sci. 2009, 117, 95-109. [CrossRef] [PubMed]

104. Gu, L.; Okada, Y.; Clinton, S.K.; Gerard, C.; Sukhova, G.K.; Libby, P.; Rollins, B.J. Absence of Monocyte Chemoattractant Protein-1 Reduces Atherosclerosis in Low Density Lipoprotein Receptor-Deficient Mice. Mol. Cell 1998, 2, 275-281. [CrossRef]

105. Boring, L.; Gosling, J.; Cleary, M.L.; Charo, I.F. Decreased lesion formation in CCR2-/ - mice reveals a role for chemokines in the initiation of atherosclerosis. Nature 1998, 394, 894-897. [CrossRef]

106. Aiello, R.J.; Bourassa, P.-A.K.; Lindsey, S.; Weng, W.; Natoli, E.; Rollins, B.J.; Milos, P.M. Monocyte Chemoattractant Protein-1 Accelerates Atherosclerosis in Apolipoprotein E-Deficient Mice. Arterioscler. Thromb. Vasc. Biol. 1999, 19, 1518-1525. [CrossRef]

107. Zhang, X.; Liu, X.; Shang, H.; Xu, Y.; Qian, M. Monocyte chemoattractant protein-1 induces endothelial cell apoptosis in vitro through a p53-dependent mitochondrial pathway. Acta Biochim. Biophys. Sin. 2011, 43, 787-795. [CrossRef]

108. Tousoulis, D.; Antoniades, C.; Bosinakou, E.; Kotsopoulou, M.; Tsoufis, C.; Marinou, K.; Charakida, M.; Stefanadi, E.; Vavuranakis, M.; Latsios, G.; et al. Differences in inflammatory and thrombotic markers between unstable angina and acute myocardial infarction. Int. J. Cardiol. 2007, 115, 203-207. [CrossRef] [PubMed]

109. Stefanadi, E.; Tousoulis, D.; Androulakis, E.S.; Papageorgiou, N.; Charakida, M.; Siasos, G.; Tsioufis, C.; Stefanadis, C. Inflammatory Markers in Essential Hypertension: Potential Clinical Implications. Curr. Vasc. Pharmacol. 2010, 8, 509-516. [CrossRef]

110. Tousoulis, D.; Daves, G.J.M.D.; Asimakopoulos, M.D.; Homaei, H.; Zouridakis, E.M.D.; Ahmed, N.; Kaski, J.C. Vascular cell adhesion molecule-1 and intercellular adhesion molecule-1 serum level in patients with chest pain and normal coronary arteries (syndrome X). Clin. Cardiol. 2001, 24, 301-304. [CrossRef]

111. Tousoulis, D.; Homaei, H.; Ahmed, N.; Asimakopoulos, G.; Zouridakis, E.; Toutouzas, P.; Davies, G.J. Increased plasma adhesion molecule levels in patients with heart failure who have ischemic heart disease and dilated cardiomyopathy. Am. Heart J. 2001, 141, 277-280. [CrossRef]

112. Tousoulis, D.; Papageorgiou, N.; Androulakis, E.; Siasos, G.; Latsios, G.; Tentolouris, K.; Stefanadis, C. Diabetes MellitusAssociated Vascular Impairment: Novel Circulating Biomarkers and Therapeutic Approaches. J. Am. Coll. Cardiol. 2013, 62, 667-676. [CrossRef] [PubMed]

113. Pititto, B.D.A.; Ribeiro-Filho, F.F.; Bittencourt, M.S.; Lotufo, P.A.; Bensenor, I.; Ferreira, S.R.G. Usefulness of circulating E-selectin to early detection of the atherosclerotic process in the Brazilian Longitudinal Study of Adult Health (ELSA-Brasil). Diabetol. Metab. Syndr. 2016, 8, 19. [CrossRef]

114. Ridker, P.M.; Buring, J.E.; Rifai, N. Soluble P-Selectin and the Risk of Future Cardiovascular Events. Circulation 2001, $103,491-495$. [CrossRef] [PubMed]

115. Hwang, S.-J.; Ballantyne, C.M.; Sharrett, A.R.; Smith, L.C.; Davis, C.E.; Gotto, A.M.; Boerwinkle, E. Circulating Adhesion Molecules VCAM-1, ICAM-1, and E-selectin in Carotid Atherosclerosis and Incident Coronary Heart Disease Cases. Circulation 1997, 96, 4219-4225. [CrossRef] 
116. Schmidt, C.; Hulthe, J.; Fagerberg, B. Baseline ICAM-1 and VCAM-1 are Increased in Initially Healthy Middle-Aged Men who Develop Cardiovascular Disease during 6.6 Years of Follow-Up. Angiology 2009, 60, 108-114. [CrossRef] [PubMed]

117. Hillis, G.S.; Terregino, C.; Taggart, P.; Killian, A.; Zhao, N.; Dalsey, W.C.; Mangione, A. Elevated soluble P-selectin levels are associated with an increased risk of early adverse events in patients with presumed myocardial ischemia. Am. Heart J. 2002, 143, 235-241. [CrossRef] [PubMed]

118. Hoogeveen, R.C.; Morrison, A.; Boerwinkle, E.; Miles, J.S.; Rhodes, C.E.; Sharrett, A.R.; Ballantyne, C.M. Plasma MCP-1 level and risk for peripheral arterial disease and incident coronary heart disease: Atherosclerosis Risk in Communities study. Atherosclerosis 2005, 183, 301-307. [CrossRef]

119. Drummond, G.R.; Sobey, C.G. Endothelial NADPH oxidases: Which NOX to target in vascular disease? Trends Endocrinol. Metab. 2014, 25, 452-463. [CrossRef]

120. Xia, F.; Wang, C.; Jin, Y.; Liu, Q.; Meng, Q.; Liu, K.; Sun, H. Luteolin Protects HUVECs from TNF- $\alpha$-induced Oxidative Stress and Inflammation via its Effects on the Nox4/ROS-NF-kB and MAPK Pathways. J. Atheroscler. Thromb. 2014, 21, 768-783. [CrossRef] [PubMed]

121. Xiao, H.; Lu, M.; Lin, T.Y.; Chen, Z.; Chen, G.; Wang, W.-C.; Marin, T.; Shentu, T.-P.; Wen, L.; Gongol, B.; et al. Sterol Regulatory Element Binding Protein 2 Activation of NLRP3 Inflammasome in Endothelium Mediates Hemodynamic-Induced Atherosclerosis Susceptibility. Circulation 2013, 128, 632-642. [CrossRef]

122. Döring, Y.; Libby, P.; Soehnlein, O. Neutrophil extracellular traps participate in cardiovascular diseases: Recent experimental and clinical insights. Circ. Res. 2020, 126, 1228-1241. [CrossRef]

123. Pieterse, E.; Rother, N.; Garsen, M.; Hofstra, J.M.; Satchell, S.C.; Hoffmann, M.; Loeven, M.A.; Knaapen, H.K.; van der Heijden, O.W.; Berden, J.H.; et al. Neutrophil Extracellular Traps Drive Endothelial-to-Mesenchymal Transition. Arterioscler. Thromb. Vasc. Biol. 2017, 37, 1371-1379. [CrossRef]

124. Wang, H.; Wang, C.; Zhao, M.; Chen, M. Neutrophil extracellular traps can activate alternative complement pathways. Clin. Exp. Immunol. 2015, 181, 518-527. [CrossRef]

125. Wang, L.; Zhou, X.; Yin, Y.; Mai, Y.; Wang, D.; Zhang, X. Hyperglycemia Induces Neutrophil Extracellular Traps Formation through an NADPH Oxidase-Dependent Pathway in Diabetic Retinopathy. Front. Immunol. 2019, 9, 3076. [CrossRef]

126. Hirota, T.; Levy, J.H.; Iba, T. The influence of hyperglycemia on neutrophil extracellular trap formation and endothelial glycocalyx damage in a mouse model of type 2 diabetes. Microcirculation 2020, 27, 12617. [CrossRef] [PubMed]

127. Obama, T.; Ohinata, H.; Takaki, T.; Iwamoto, S.; Sawada, N.; Aiuchi, T.; Kato, R.; Itabe, H. Cooperative Action of Oxidized Low-Density Lipoproteins and Neutrophils on Endothelial Inflammatory Responses Through Neutrophil Extracellular Trap Formation. Front. Immunol. 2019, 10, 1899. [CrossRef] [PubMed]

128. Wang, H.; Wang, Q.; Venugopal, J.; Wang, J.; Kleiman, K.; Guo, C.; Eitzman, D.T. Obesity-induced Endothelial Dysfunction is Prevented by Neutrophil Extracellular Trap Inhibition. Sci. Rep. 2018, 8, 4881. [CrossRef] [PubMed]

129. Jalali, S.; del Pozo, M.A.; Chen, K.-D.; Miao, H.; Li, Y.-S.; Schwartz, M.A.; Shyy, J.Y.-J.; Chien, S. Integrin-mediated mechanotransduction requires its dynamic interaction with specific extracellular matrix (ECM) ligands. Proc. Natl. Acad. Sci. USA 2001, 98, 1042-1046. [CrossRef] [PubMed]

130. Kuchan, M.J.; Jo, H.; Frangos, J.A. Role of G proteins in shear stress-mediated nitric oxide production by endothelial cells. Am. J. Physiol. Cell Physiol. 1994, 267, C753-C758. [CrossRef]

131. Pan, S. Molecular Mechanisms Responsible for the Atheroprotective Effects of Laminar Shear Stress. Antioxid. Redox Signal. 2009, 11, 1669-1682. [CrossRef]

132. Boo, Y.C.; Kim, H.J.; Song, H.; Fulton, D.; Sessa, W.; Jo, H. Coordinated regulation of endothelial nitric oxide synthase activity by phosphorylation and subcellular localization. Free Radic. Biol. Med. 2006, 41, 144-153. [CrossRef]

133. Dimmeler, S.; Fleming, I.; Fisslthaler, B.; Hermann, C.; Busse, R.; Zeiher, A.M. Activation of nitric oxide synthase in endothelial cells by Akt-dependent phosphorylation. Nature 1999, 399, 601-605. [CrossRef] [PubMed]

134. Passerini, A.; Polacek, D.C.; Shi, C.; Francesco, N.M.; Manduchi, E.; Grant, G.; Pritchard, W.F.; Powell, S.; Chang, G.Y.; Stoeckert, C.J.; et al. Coexisting proinflammatory and antioxidative endothelial transcription profiles in a disturbed flow region of the adult porcine aorta. Proc. Natl. Acad. Sci. USA 2004, 101, 2482-2487. [CrossRef] [PubMed]

135. Warabi, E.; Takabe, W.; Minami, T.; Inoue, K.; Itoh, K.; Yamamoto, M.; Ishii, T.; Kodama, T.; Noguchi, N. Shear stress stabilizes NF-E2-related factor 2 and induces antioxidant genes in endothelial cells: Role of reactive oxygen/nitrogen species. Free Radic. Biol. Med. 2007, 42, 260-269. [CrossRef]

136. SenBanerjee, S.; Lin, Z.; Atkins, G.B.; Greif, D.M.; Rao, R.M.; Kumar, A.; Feinberg, M.W.; Chen, Z.; Simon, D.I.; Luscinskas, F.W.; et al. KLF2 Is a Novel Transcriptional Regulator of Endothelial Proinflammatory Activation. J. Exp. Med. 2004, 199, $1305-1315$. [CrossRef]

137. Hayashi, S.-I.; Rakugi, H.; Morishita, R. Insight into the Role of Angiopoietins in Ageing-Associated Diseases. Cells 2020, 9 , 2636. [CrossRef] [PubMed]

138. Wang, L.; Luo, J.-Y.; Li, B.; Tian, X.Y.; Chen, L.-J.; Huang, Y.; Liu, J.; Deng, D.; Lau, C.W.; Wan, S.; et al. Integrin-YAP/TAZ-JNK cascade mediates atheroprotective effect of unidirectional shear flow. Nature 2016, 540, 579-582. [CrossRef]

139. Wang, K.-C.; Yeh, Y.-T.; Nguyen, P.; Limqueco, E.; Lopez, J.; Thorossian, S.; Guan, K.-L.; Li, Y.-S.J.; Chien, S. Flow-dependent YAP/TAZ activities regulate endothelial phenotypes and atherosclerosis. Proc. Natl. Acad. Sci. USA 2016, 113, 11525-11530. [CrossRef] 
140. Serbanovic-Canic, J.; de Luca, A.; Warboys, C.; Ferreira, P.F.; Luong, L.A.; Hsiao, S.; Gauci, I.; Mahmoud, M.; Feng, S.; Souilhol, C.; et al. Zebrafish Model for Functional Screening of Flow-Responsive Genes. Arterioscler. Thromb. Vasc. Biol. 2017, 37, 130-143. [CrossRef]

141. Mahmoud, M.M.; Kim, H.R.; Xing, R.; Hsiao, S.; Mammmoto, A.; Chen, J.; Serbanovic-Canic, J.; Feng, S.; Bowden, N.P.; Maguire, R.; et al. TWIST1 Integrates Endothelial Responses to Flow in Vascular Dysfunction and Atherosclerosis. Circ. Res. 2016, 119, 450-462. [CrossRef]

142. Kim, C.W.; Song, H.; Kumar, S.; Nam, D.; Kwon, H.S.; Chang, K.H.; Son, D.J.; Kang, D.-W.; Brodie, S.A.; Weiss, D.; et al. Anti-Inflammatory and Antiatherogenic Role of BMP Receptor II in Endothelial Cells. Arterioscler. Thromb. Vasc. Biol. 2013, 33, 1350-1359. [CrossRef]

143. Gelfand, B.D.; Meller, J.; Pryor, A.W.; Kahn, M.; Bortz, P.D.S.; Wamhoff, B.R.; Blackman, B.R. Hemodynamic Activation of $\beta$ Catenin and T-Cell-Specific Transcription Factor Signaling in Vascular Endothelium Regulates Fibronectin Expression. Arterioscler. Thromb. Vasc. Biol. 2011, 31, 1625-1633. [CrossRef]

144. Wang, S.; Aurora, A.B.; Johnson, B.A.; Qi, X.; McAnally, J.; Hill, J.A.; Richardson, J.A.; Bassel-Duby, R.; Olson, E.N. The Endothelial-Specific MicroRNA miR-126 Governs Vascular Integrity and Angiogenesis. Dev. Cell 2008, 15, 261-271. [CrossRef]

145. Harris, T.A.; Yamakuchi, M.; Ferlito, M.; Mendell, J.T.; Lowenstein, C.J. MicroRNA-126 regulates endothelial expression of vascular cell adhesion molecule 1. Proc. Natl. Acad. Sci. USA 2008, 105, 1516-1521. [CrossRef] [PubMed]

146. Schober, A.; Nazari-Jahantigh, M.; Wei, Y.; Bidzhekov, K.; Gremse, F.; Grommes, J.; Megens, R.; Heyll, K.; Noels, H.; Hristov, M.; et al. MicroRNA-126-5p promotes endothelial proliferation and limits atherosclerosis by suppressing Dlk1. Nat. Med. 2014, 20, 368-376. [CrossRef]

147. Tang, F.; Yang, T.-L. MicroRNA-126 alleviates endothelial cells injury in atherosclerosis by restoring autophagic flux via inhibiting of PI3K/Akt/mTOR pathway. Biochem. Biophys. Res. Commun. 2018, 495, 1482-1489. [CrossRef] [PubMed]

148. Tang, S.-T.; Wang, F.; Shao, M.; Wang, Y.; Zhu, H.-Q. MicroRNA-126 suppresses inflammation in endothelial cells under hyperglycemic condition by targeting HMGB1. Vasc. Pharmacol. 2017, 88, 48-55. [CrossRef]

149. Chen, H.; Li, X.; Liu, S.; Gu, L.; Zhou, X. MircroRNA-19a promotes vascular inflammation and foam cell formation by targeting HBP-1 in atherogenesis. Sci. Rep. 2017, 7, 12089. [CrossRef]

150. Loyer, X.; Potteaux, S.; Vion, A.-C.; Guérin, C.L.; Boulkroun, S.; Rautou, P.-E.; Ramkhelawon, B.; Esposito, B.; Dalloz, M.; Paul, J.-L.; et al. Inhibition of MicroRNA-92a Prevents Endothelial Dysfunction and Atherosclerosis in Mice. Circ. Res. 2014, 114, 434-443. [CrossRef] [PubMed]

151. Ni, C.-W.; Qiu, H.; Jo, H. MicroRNA-663 upregulated by oscillatory shear stress plays a role in inflammatory response of endothelial cells. Am. J. Physiol. Heart Circ. Physiol. 2011, 300, H1762-H1769. [CrossRef]

152. Son, D.J.; Kumar, S.; Takabe, W.; Kim, C.W.; Ni, C.-W.; Alberts-Grill, N.; Jang, I.-H.; Kim, S.; Kim, W.; Kang, S.W.; et al. The atypical mechanosensitive microRNA-712 derived from pre-ribosomal RNA induces endothelial inflammation and atherosclerosis. Nat. Commun. 2013, 4, 3000. [CrossRef]

153. Xu, X.; Yang, Y.; Wang, G.; Yin, Y.; Han, S.; Zheng, D.; Zhou, S.; Zhao, Y.; Chen, Y.; Jin, Y. Low shear stress regulates vascular endothelial cell pyroptosis through miR-181b-5p/STAT-3 axis. J. Cell. Physiol. 2021, 236, 318-327. [CrossRef] [PubMed]

154. Steyers, C.M., III; Miller, F.J., Jr. Endothelial Dysfunction in Chronic Inflammatory Diseases. Int. J. Mol. Sci. 2014, 15, 11324-11349. [CrossRef] [PubMed]

155. Di Minno, M.N.D.; Ambrosino, P.; Lupoli, R.; Di Minno, A.; Tasso, M.; Peluso, R.; Tremoli, E. Clinical assessment of endothelial function in patients with rheumatoid arthritis: A meta-analysis of literature studies. Eur. J. Intern. Med. 2015, 26, 835-842. [CrossRef] [PubMed]

156. Bordy, R.; Totoson, P.; Prati, C.; Marie, C.; Wendling, D.; Demougeot, C. Microvascular endothelial dysfunction in rheumatoid arthritis. Nat. Rev. Rheumatol. 2018, 14, 404-420. [CrossRef] [PubMed]

157. Fernández-Nebro, A.; Rúa-Figueroa, İ.; López-Longo, F.J.; Galindo, M.; Calvo-Alén, J.; Olivé-Marqués, A.; Cañizares, M.D.C.O.; Martín-Martínez, M.A.; Blanco, R.; Melero-González, R.; et al. Cardiovascular Events in Systemic Lupus Erythematosus: A Nationwide Study in Spain from the RELESSER Registry. Medicine 2015, 94, e1183. [CrossRef] [PubMed]

158. Mendoza-Pinto, C.; Rojas-Villarraga, A.; Molano-González, N.; García-Carrasco, M.; Munguía-Realpozo, P.; Etchegaray-Morales, I.; Morales-Sánchez, H.; Berra-Romani, R.; Cervera, R. Endothelial dysfunction and arterial stiffness in patients with systemic lupus erythematosus: A systematic review and meta-analysis. Atherosclerosis 2020, 297, 55-63. [CrossRef]

159. Alba, B.K.; Greaney, J.L.; Ferguson, S.B.; Alexander, L.M. Endothelial function is impaired in the cutaneous microcirculation of adults with psoriasis through reductions in nitric oxide-dependent vasodilation. Am. J. Physiol. Heart Circ. Physiol. 2018, 314, H343-H349. [CrossRef]

160. Weber, B.N.; Stevens, E.; Perez-Chada, L.M.; Brown, J.M.; Divakaran, S.; Bay, C.; Bibbo, C.; Hainer, J.; Dorbala, S.; Blankstein, R.; et al. Impaired Coronary Vasodilator Reserve and Adverse Prognosis in Patients with Systemic Inflammatory Disorders. JACC Cardiovasc. Imaging 2021. [CrossRef]

161. Gravina, A.G.; Dallio, M.; Masarone, M.; Rosato, V.; Aglitti, A.; Persico, M.; Loguercio, C.; Federico, A. Vascular Endothelial Dysfunction in Inflammatory Bowel Diseases: Pharmacological and Nonpharmacological Targets. Oxidative Med. Cell. Longev. 2018, 2018, 2568569. [CrossRef]

162. Borissoff, J.I.; Spronk, H.M.; Cate, H.T. The Hemostatic System as a Modulator of Atherosclerosis. N. Engl. J. Med. 2011, 364, 1746-1760. [CrossRef] 
163. Del Turco, S.; Basta, G.; Lazzerini, G.; Chancharme, L.; Lerond, L.; De Caterina, R. Involvement of the TP receptor in TNF- $\alpha-$ induced endothelial tissue factor expression. Vasc. Pharmacol. 2014, 62, 49-56. [CrossRef]

164. Bavendiek, U.; Libby, P.; Kilbride, M.; Reynolds, R.; Mackman, N.; Schönbeck, U. Induction of Tissue Factor Expression in Human Endothelial Cells by CD40 Ligand Is Mediated via Activator Protein 1, Nuclear Factor kB, and Egr-1. J. Biol. Chem. 2002, 277, 25032-25039. [CrossRef] [PubMed]

165. Szotowski, B.; Antoniak, S.; Poller, W.; Schultheiss, H.-P.; Rauch, U. Procoagulant Soluble Tissue Factor Is Released from Endothelial Cells in Response to Inflammatory Cytokines. Circ. Res. 2005, 96, 1233-1239. [CrossRef]

166. Cohen, C.T.; Turner, N.A.; Moake, J.L. Production and control of coagulation proteins for factor X activation in human endothelial cells and fibroblasts. Sci. Rep. 2020, 10, 2005. [CrossRef] [PubMed]

167. Conway, E.M. A Nuclear Attack on Thrombosis and Inflammation. Arterioscler. Thromb. Vasc. Biol. 2016, 36, 221-223. [CrossRef] [PubMed]

168. Adams, T.E.; Huntington, J.A. Thrombin-Cofactor Interactions: Structural Insights into Regulatory Mechanisms. Arterioscler. Thromb. Vasc. Biol. 2006, 26, 1738-1745. [CrossRef]

169. Anastasiou, G.; Gialeraki, A.; Merkouri, E.; Politou, M.; Travlou, A. Thrombomodulin as a regulator of the anticoagulant pathway: Implication in the development of thrombosis. Blood Coagul. Fibrinolysis 2012, 23, 1-10. [CrossRef] [PubMed]

170. Yang, P.; Wei, X.; Zhang, J.; Yi, B.; Zhang, G.-X.; Yin, L.; Yang, X.-F.; Sun, J. Antithrombotic Effects of Nur77 and Nor1 Are Mediated Through Upregulating Thrombomodulin Expression in Endothelial Cells. Arterioscler. Thromb. Vasc. Biol. 2016, 36, 361-369. [CrossRef]

171. Nan, B.; Yang, H.; Yan, S.; Lin, P.H.; Lumsden, A.B.; Yao, Q.; Chen, C. C-reactive protein decreases expression of thrombomodulin and endothelial protein $C$ receptor in human endothelial cells. Surgery 2005, 138, 212-222. [CrossRef]

172. Ishii, H.; Tezuka, T.; Ishikawa, H.; Takada, K.; Oida, K.; Horie, S. Oxidized phospholipids in oxidized low-density lipoprotein down-regulate thrombomodulin transcription in vascular endothelial cells through a decrease in the binding of RAR $\beta$-RXR $\alpha$ heterodimers and Sp1 and Sp3 to their binding sequences in the TM promoter. Blood 2003, 101, 4765-4774. [CrossRef] [PubMed]

173. Dhanesha, N.; Prakash, P.; Doddapattar, P.; Khanna, I.; Pollpeter, M.J.; Nayak, M.K.; Staber, J.M.; Chauhan, A.K. Endothelial Cell-Derived von Willebrand Factor Is the Major Determinant That Mediates von Willebrand Factor-Dependent Acute Ischemic Stroke by Promoting Postischemic Thrombo-Inflammation. Arterioscler. Thromb. Vasc. Biol. 2016, 36, 1829-1837. [CrossRef] [PubMed]

174. Doddapattar, P.; Dhanesha, N.; Chorawala, M.R.; Tinsman, C.; Jain, M.; Nayak, M.K.; Staber, J.M.; Chauhan, A.K. Endothelial Cell-Derived Von Willebrand Factor, But Not Platelet-Derived, Promotes Atherosclerosis in Apolipoprotein E-Deficient Mice. Arterioscler. Thromb. Vasc. Biol. 2018, 38, 520-528. [CrossRef]

175. Vischer, U.M.; Barth, H.; Wollheim, C.B. Regulated von Willebrand Factor Secretion Is Associated with Agonist-Specific Patterns of Cytoskeletal Remodeling in Cultured Endothelial Cells. Arterioscler. Thromb. Vasc. Biol. 2000, 20, 883-891. [CrossRef] [PubMed]

176. Bernardo, A.; Ball, C.; Nolasco, L.; Moake, J.F.; Dong, J.-F. Effects of inflammatory cytokines on the release and cleavage of the endothelial cell-derived ultralarge von Willebrand factor multimers under flow. Blood 2004, 104, 100-106. [CrossRef] [PubMed]

177. Gragnano, F.; Sperlongano, S.; Golia, E.; Natale, F.; Bianchi, R.; Crisci, M.; Fimiani, F.; Pariggiano, I.; Diana, V.; Carbone, A.; et al. The Role of von Willebrand Factor in Vascular Inflammation: From Pathogenesis to Targeted Therapy. Mediat. Inflamm. 2017, 2017, 5620314. [CrossRef]

178. Delabranche, X.; Helms, J.; Meziani, F. Immunohaemostasis: A new view on haemostasis during sepsis. Ann. Intensiv. Care 2017, 7, 117. [CrossRef]

179. Engelmann, B.; Massberg, S. Thrombosis as an intravascular effector of innate immunity. Nat. Rev. Immunol. 2012, 13, 34-45. [CrossRef]

180. Bonaventura, A.; Vecchié, A.; Dagna, L.; Martinod, K.; Dixon, D.L.; Van Tassell, B.W.; Dentali, F.; Montecucco, F.; Massberg, S.; Levi, M.; et al. Endothelial dysfunction and immunothrombosis as key pathogenic mechanisms in COVID-19. Nat. Rev. Immunol. 2021, 21, 319-329. [CrossRef]

181. Green, D.J.; Jones, H.; Thijssen, D.; Cable, N.T.; Atkinson, G. Flow-Mediated Dilation and Cardiovascular Event Prediction: Does Nitric Oxide Matter? Hypertension 2011, 57, 363-369. [CrossRef]

182. Matsuzawa, Y.; Kwon, T.; Lennon, R.J.; Lerman, L.O.; Lerman, A. Prognostic Value of Flow-Mediated Vasodilation in Brachial Artery and Fingertip Artery for Cardiovascular Events: A Systematic Review and Meta-Analysis. J. Am. Heart Assoc. 2015, 4, e002270. [CrossRef]

183. Fuchsjäger-Mayrl, G.; Pleiner, J.; Wiesinger, G.F.; Sieder, A.E.; Quittan, M.; Nuhr, M.J.; Francesconi, C.; Seit, H.-P.; Francesconi, M.; Schmetterer, L.; et al. Exercise training improves vascular endothelial function in patients with type 1 diabetes. Diabetes Care 2002, 25, 1795-1801. [CrossRef]

184. Pedralli, M.L.; Marschner, R.A.; Kollet, D.P.; Neto, S.G.; Eibel, B.; Tanaka, H.; Lehnen, A.M. Different exercise training modalities produce similar endothelial function improvements in individuals with prehypertension or hypertension: A randomized clinical trial. Sci. Rep. 2020, 10, 7628. [CrossRef] [PubMed]

185. A Brown, A.; Hu, F.B. Dietary modulation of endothelial function: Implications for cardiovascular disease. Am. J. Clin. Nutr. 2001, 73, 673-686. [CrossRef] [PubMed] 
186. Johnson, H.; Gossett, L.K.; Piper, M.E.; Aeschlimann, S.E.; Korcarz, C.; Baker, T.B.; Fiore, M.C.; Stein, J.H. Effects of Smoking and Smoking Cessation on Endothelial Function: 1-Year Outcomes from a Randomized Clinical Trial. J. Am. Coll. Cardiol. 2010, 55, 1988-1995. [CrossRef]

187. Oikonomou, E.; Siasos, G.; Zaromitidou, M.; Hatzis, G.; Mourouzis, K.; Chrysohoou, C.; Zisimos, K.; Mazaris, S.; Tourikis, P.; Athanasiou, D.; et al. Atorvastatin treatment improves endothelial function through endothelial progenitor cells mobilization in ischemic heart failure patients. Atherosclerosis 2015, 238, 159-164. [CrossRef] [PubMed]

188. Reriani, M.K.; Dunlay, S.M.; Gupta, B.; West, C.P.; Rihal, C.S.; O Lerman, L.; Lerman, A. Effects of statins on coronary and peripheral endothelial function in humans: A systematic review and meta-analysis of randomized controlled trials. Eur. J. Cardiovasc. Prev. Rehabil. 2011, 18, 704-716. [CrossRef]

189. Gounari, P.; Tousoulis, D.; Antoniades, C.; Kampoli, A.M.; Stougiannos, P.; Papageorgiou, N.; Roulia, G.; Stefanadi, E.; Siasos, G.; Tsioufis, C.; et al. Rosuvastatin but not ezetimibe improves endothelial function in patients with heart failure, by mechanisms independent of lipid lowering. Int. J. Cardiol. 2010, 142, 87-91. [CrossRef]

190. Alshnbari, A.S.; Millar, S.A.; O'Sullivan, S.E.; Idris, I. Effect of Sodium-Glucose Cotransporter-2 Inhibitors on Endothelial Function: A Systematic Review of Preclinical Studies. Diabetes Ther. 2020, 11, 1947-1963. [CrossRef] [PubMed]

191. Zhao, Q.; Xu, H.; Zhang, L.; Liu, L.; Wang, L. GLP-1 receptor agonist lixisenatide protects against high free fatty acids-induced oxidative stress and inflammatory response. Artif. Cells Nanomed. Biotechnol. 2019, 47, 2325-2332. [CrossRef] [PubMed]

192. Sukumaran, V.; Tsuchimochi, H.; Sonobe, T.; Waddingham, M.T.; Shirai, M.; Pearson, J.T. Liraglutide treatment improves the coronary microcirculation in insulin resistant Zucker obese rats on a high salt diet. Cardiovasc. Diabetol. 2020, 19, 24. [CrossRef] [PubMed]

193. Kajikawa, M.; Higashi, Y.; Tomiyama, H.; Maruhashi, T.; Kurisu, S.; Kihara, Y.; Mutoh, A.; Ueda, S.-I. Effect of short-term colchicine treatment on endothelial function in patients with coronary artery disease. Int. J. Cardiol. 2019, 281, 35-39. [CrossRef]

194. Yang, M.; Lv, H.; Liu, Q.; Zhang, L.; Zhang, R.; Huang, X.; Wang, X.; Han, B.; Hou, S.; Liu, D.; et al. Colchicine Alleviates Cholesterol Crystal-Induced Endothelial Cell Pyroptosis through Activating AMPK/SIRT1 Pathway. Oxidative Med. Cell. Longev. 2020, 2020, 9173530. [CrossRef] [PubMed]

195. Hebbel, R.P.; Wei, P.; Milbauer, L.; Corban, M.T.; Solovey, A.; Kiley, J.; Pattee, J.; Lerman, L.O.; Pan, W.; Lerman, A. Abnormal Endothelial Gene Expression Associated with Early Coronary Atherosclerosis. J. Am. Heart Assoc. 2020, 9, e016134. [CrossRef] [PubMed]

196. LaLonde, S.; Codina-Fauteux, V.-A.; De Bellefon, S.M.; Leblanc, F.; Beaudoin, M.; Simon, M.-M.; Dali, R.; Kwan, T.; Lo, K.S.; Pastinen, T.; et al. Integrative analysis of vascular endothelial cell genomic features identifies AIDA as a coronary artery disease candidate gene. Genome Biol. 2019, 20, 133. [CrossRef] [PubMed]

197. Stolze, L.K.; Conklin, A.C.; Whalen, M.B.; Rodríguez, M.L.; Ôunap, K.; Selvarajan, I.; Toropainen, A.; Örd, T.; Li, J.; Eshghi, A.; et al. Systems Genetics in Human Endothelial Cells Identifies Non-coding Variants Modifying Enhancers, Expression, and Complex Disease Traits. Am. J. Hum. Genet. 2020, 106, 748-763. [CrossRef]

198. Li, Y.; Yan, H.; Guo, J.; Han, Y.; Zhang, C.; Liu, X.; Du, J.; Tian, X.-L. Down-regulated RGS5 by genetic variants impairs endothelial cell function and contributes to coronary artery disease. Cardiovasc. Res. 2021, 117, 240-255. [CrossRef] [PubMed]

199. Bai, B.; Yang, Y.; Ji, S.; Wang, S.; Peng, X.; Tian, C.; Sun, R.; Yu, T.; Chu, X. MicroRNA-302c-3p inhibits endothelial cell pyroptosis via directly targeting NOD-, LRR- and pyrin domain-containing protein 3 in atherosclerosis. J. Cell. Mol. Med. 2021, 25, $4373-4386$ [CrossRef]

200. Zhou, W.; Xi, D.; Shi, Y.; Wang, L.; Zhong, H.; Huang, Z.; Liu, Y.; Tang, Y.; Lu, N.; Wang, Y.; et al. MicroRNA-1929-3p participates in murine cytomegalovirus-induced hypertensive vascular remodeling through Ednra/NLRP3 inflammasome activation. Int. J. Mol. Med. 2020, 47, 719-731. [CrossRef]

201. Zhou, T.; Xiang, D.-K.; Li, S.-N.; Yang, L.-H.; Gao, L.-F.; Feng, C. MicroRNA-495 Ameliorates Cardiac Microvascular Endothelial Cell Injury and Inflammatory Reaction by Suppressing the NLRP3 Inflammasome Signaling Pathway. Cell. Physiol. Biochem. 2018, 49, 798-815. [CrossRef] [PubMed]

202. Dong, F.; Dong, S.; Liang, Y.; Wang, K.; Qin, Y.; Zhao, X. miR-20b inhibits the senescence of human umbilical vein endothelial cells through regulating the Wnt/ $\beta$-catenin pathway via the TXNIP/NLRP3 axis. Int. J. Mol. Med. 2020, 45, 847-857. [CrossRef] [PubMed]

203. Jiao, Y.; Zhao, D.; Gao, F.; Hu, X.; Hu, X.; Li, M.; Cui, Y.; Wei, X.; Xie, C.; Zhao, Y.; et al. MicroRNA-520c-3p suppresses vascular endothelium dysfunction by targeting RELA and regulating the AKT and NF-kB signaling pathways. J. Physiol. Biochem. 2021, 77, 47-61. [CrossRef]

204. Yang, S.; Chen, Y.; Mi, X.; Zhang, S.; Yang, Y.; Hui, R.; Zhang, W. MicroRNA-216a Promotes Endothelial Inflammation by Smad7/IкB $\alpha$ Pathway in Atherosclerosis. Dis. Markers 2020, 2020, 8864322. [CrossRef] [PubMed]

205. Li, Q.; Yao, Y.; Shi, S.; Zhou, M.; Zhou, Y.; Wang, M.; Chiu, J.; Huang, Z.; Zhang, W.; Liu, M.; et al. Inhibition of miR-21 alleviated cardiac perivascular fibrosis via repressing EndMT in T1DM. J. Cell. Mol. Med. 2020, 24, 910-920. [CrossRef] [PubMed]

206. Cai, Y.; Zhang, Y.; Chen, H.; Sun, X.-H.; Zhang, P.; Zhang, L.; Liao, M.-Y.; Zhang, F.; Xia, Z.-Y.; Man, R.Y.-K.; et al. MicroRNA-17-3p suppresses NF-KB-mediated endothelial inflammation by targeting NIK and IKK $\beta$ binding protein. Acta Pharmacol. Sin. 2021, 1-12. [CrossRef]

207. Yang, X.; Li, D.; Qi, Y.-Z.; Chen, W.; Yang, C.-H.; Jiang, Y.-H. MicroRNA-217 ameliorates inflammatory damage of endothelial cells induced by oxidized LDL by targeting EGR1. Mol. Cell. Biochem. 2020, 475, 41-51. [CrossRef] 
208. Wang, J.; Li, P.; Xu, X.; Zhang, B.; Zhang, J. MicroRNA-200a Inhibits Inflammation and Atherosclerotic Lesion Formation by Disrupting EZH2-Mediated Methylation of STAT3. Front. Immunol. 2020, 11, 907. [CrossRef]

209. Jiang, Z.; Wu, J.; Ma, F.; Jiang, J.; Xu, L.; Du, L.; Huang, W.; Wang, Z.; Jia, Y.; Lu, L.; et al. MicroRNA-200a improves diabetic endothelial dysfunction by targeting KEAP1/NRF2. J. Endocrinol. 2020, 245, 129-140. [CrossRef]

210. Hu, B.; Gong, Z.; Bi, Z. Inhibition of miR-383 suppresses oxidative stress and improves endothelial function by increasing sirtuin 1. Braz. J. Med Biol. Res. 2020, 53, e8616. [CrossRef]

211. Wu, J.; Liang, W.; Tian, Y.; Ma, F.; Huang, W.; Jia, Y.; Jiang, Z.; Wu, H. Inhibition of P53/miR-34a improves diabetic endothelial dysfunction via activation of SIRT1. J. Cell. Mol. Med. 2019, 23, 3538-3548. [CrossRef]

212. Li, Q.; Kim, Y.-R.; Vikram, A.; Kumar, S.; Kassan, M.; Gabani, M.; Lee, S.K.; Jacobs, J.S.; Irani, K. P66Shc-Induced MicroRNA-34a Causes Diabetic Endothelial Dysfunction by Downregulating Sirtuin1. Arterioscler. Thromb. Vasc. Biol. 2016, 36, 2394-2403. [CrossRef]

213. Kassan, M.; Vikram, A.; Li, Q.; Kim, Y.-R.; Kumar, S.; Gabani, M.; Liu, J.; Jacobs, J.S.; Irani, K. MicroRNA-204 promotes vascular endoplasmic reticulum stress and endothelial dysfunction by targeting Sirtuin1. Sci. Rep. 2017, 7, 9308. [CrossRef]

214. Su, Y.; Yuan, J.; Zhang, F.; Lei, Q.; Zhang, T.; Li, K.; Guo, J.; Hong, Y.; Bu, G.; Lv, X.; et al. MicroRNA-181a-5p and microRNA-181a$3 p$ cooperatively restrict vascular inflammation and atherosclerosis. Cell Death Dis. 2019, 10, 365. [CrossRef] [PubMed]

215. Lo, W.-Y.; Yang, W.-K.; Peng, C.-T.; Pai, W.-Y.; Wang, H.-J. MicroRNA-200a/200b Modulate High Glucose-Induced Endothelial Inflammation by Targeting O-linked N-Acetylglucosamine Transferase Expression. Front. Physiol. 2018, 9, 355. [CrossRef] 